$$
\begin{aligned}
& \text { طراحى و اعتبارسنجى الكوى مفهومى كاهش فاصلهُ برنامهٔدرسى قصد شده، اجرا } \\
& \text { شده و كسب شده در نظام آموزش عمومى ايران }
\end{aligned}
$$

\title{
Design and Validation of a Conceptual Model for Narrowing the Gaps between Intended, Implemented, and Attained Curricula in the Public Education System of Iran
}

\section{Hajitabar Firuzjani (Ph. D), H.}

Maleki (Ph. D), GH. Ahmadi (Ph. D)

\begin{abstract}
The present research aimed at developing and validating a conceptual model for narrowing the gap between intended, implemented, and attained curricula in the public education system of Iran. Two fundamental questions guided this investigation: what model can be developed to reduce the gaps between the three kinds of curricula? To what extent does the proposed model gain the approval? The research used the mixed method, in which different techniques, such as reviewing documents and inferring were employed to formulate the proposed model Based on identifying the main factors of the gaps. Therefore; the structure of this model was placed into 7 categories: theoretical foundations, desirable features of its curriculum, philosophy, purpose, direction, principles, and the methods of reducing the gaps. Likewise, to validate the proposed model, through a purposive sampling method, we sought out curriculum expert opinions, as well as opinions from specialist in the council for curriculum development. All those experts confirmed the validity of the proposed model strongly. The results revealed that developing such a model to suit the requirements of educational system in Iran would be possible.
\end{abstract}

Key words: conceptual model, curricula, intended, implemented, attained..

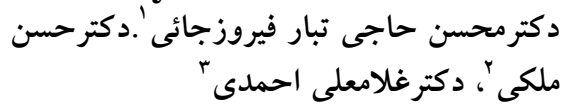

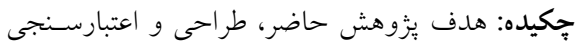

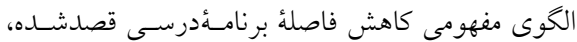

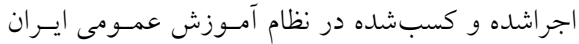

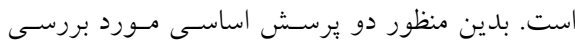

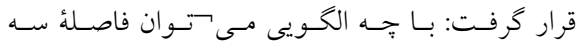

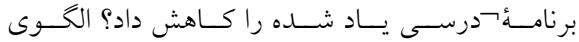

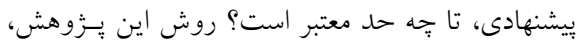

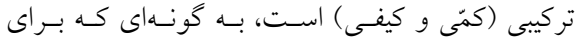

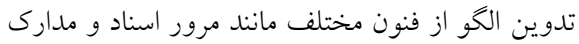

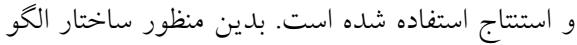

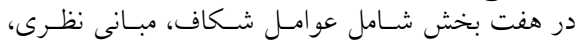

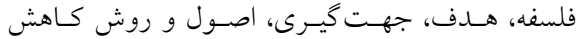

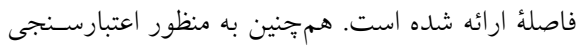

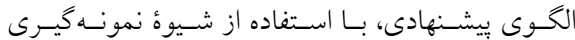

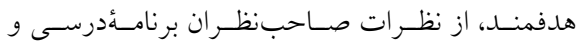

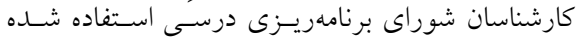

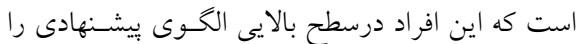

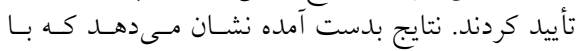

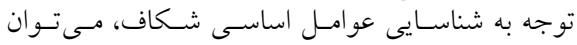

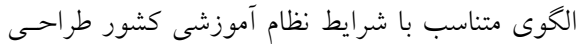

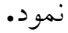
كليدوازهها: الحو مفهومى، برنامئدرسى، قصدشده،

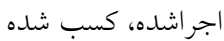

\footnotetext{
M.hajitabar@umz.ac.ir استاديار گروه علوم تربيتى دانشخاه مازندران: ( نويسنده مسئول) رايانامه

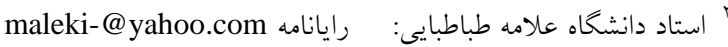

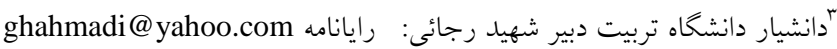




\section{مقدمه و بيان مساله}

در فرايند طراحى، توليد و اجراى برنامههاى درسى معمولاً از سه نوع برنامهُ درسى

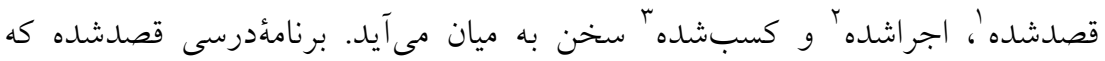

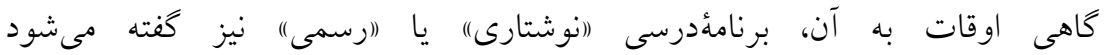

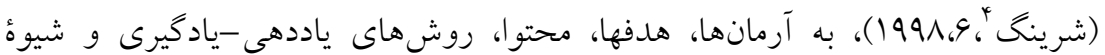

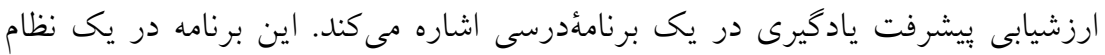

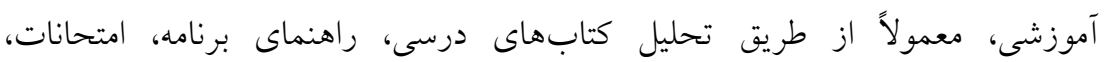

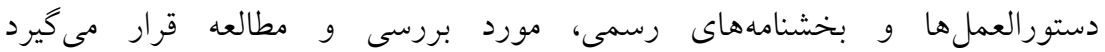

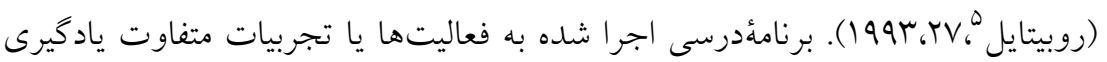

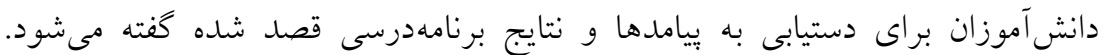

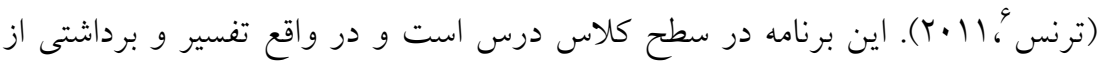

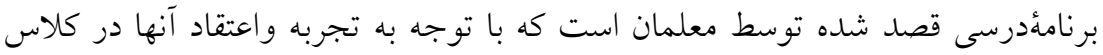

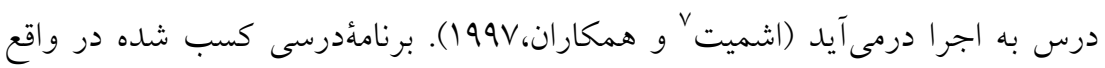

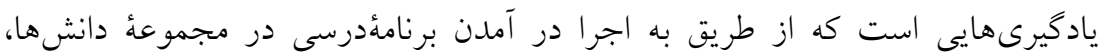

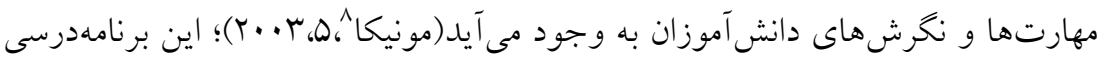

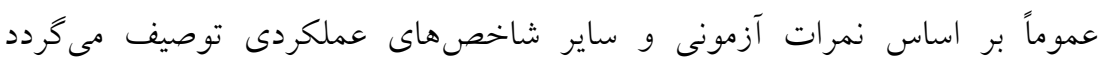

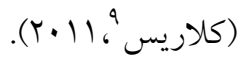

برنامهٔدرسى محصول فرايند برنامهريزى درسى است كه عملاً شامل سه مرحله

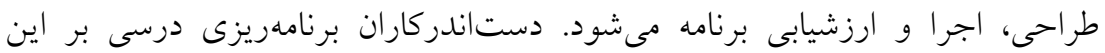

\footnotetext{
1 . Intended curriculum

2. Implemented curriculum

3 . Attained curriculum

${ }^{4}$.Tshering

${ }^{5}$.Robitaille

${ }^{6}$. Terence

7. Schmidt

${ }^{8}$. Monica

9. Clarisse
} 
طراحى و اعتبارسنجى الخوى مفهومى كاهش فاصلة برنامdٔدرسى...

باورند كه معمولاً بين آنجهه كه برنامهريزان درسى به عنوان برنامdٔدرسى قصدشده،

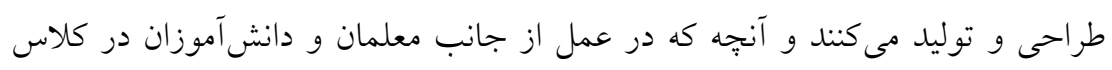
درس اجرا مىشود و آنجهه كه فراخيران در اثر اجراى برنامه قصدشده، كسب مى كنند و

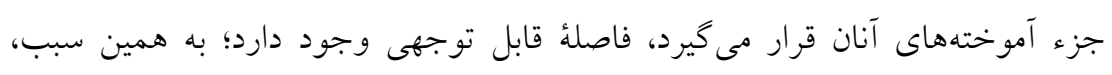
وجود هماهنكى ميان سه برنامdٔدرسى يادشده، مىتواند نمايانخر مطلوبيت و كارآيى يك

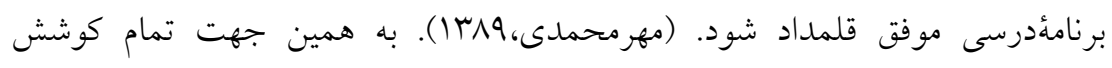
برنامهريزان درسى آن است كه با نظارت بر فرايند اجراى برنامه تا حد امكان بتوانند

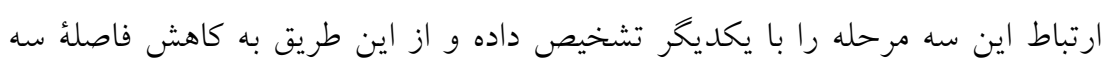
برنامdٔدرسى ياد شده، كمك كنند.

بنابراين در فرايند طراحى، توليد و اجراى برنامههاى درسى آنجه كه بيش از همه ذهن برنامهريزان درسى را به خود مشغول كرده است، ياسخ دادن به اين برسش اساسى است كه تا جهه اندازه در مراحل مختلف شكل گيرى و اجراى برنامdٔدرسى و نهايتاً آنجهه كه در عمل دانش آموزان ياد مى گيرند، هماهنخى وجود دارد. دريافت ياسخ مناسب براى اين سؤال، دستاندركاران فرايند برنامهريزى درسى را بر آن مىدارد تا با نوعى دقت و وسواس علمى كليةٌ مراحل طرحريزى، توليد و اجراى برنامئدرسى را در صحنهُ واقعى مدرسه و كلاس درس دنبال نمايند تا از اين طريق، وجود تفاوت ميان اين مراحل را به حداقل رسانده و اقدامات لازم را در جهت تصحيح حركت و ايجاد همخوانى در برنامdٔدرسى ايجاد شده، به عمل آورند.

در نظام آموزشى ايران نيز همانند بسيارى از نظامهاى آموزشى ديخر، برنامههاى درسى، معمولاً به صورت قصدشده است و آنجه كمتر مورد توجه قرار كرفته، برنامهٔدرسى اجراشده توسط معلمان و برنامٔدرسى كسبشدهُ دانش آموزان است كه از

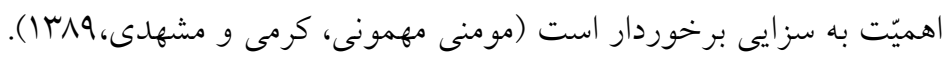
يكى از مسائلى كه همواره در مطالعات برنامdٔدرسى مد نظر بوده، وجود فاصله و در برخى موارد فقدان همسويى بين برنامهاى درسى ياد شده است كه اثربخشى 


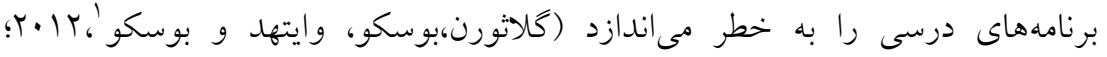

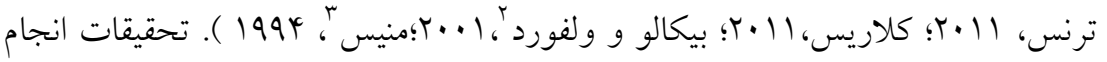
شده در كشور ما نيز حاكى از آن است كه بين سه برنامdٔدرسى قصدشده، اجراشده و

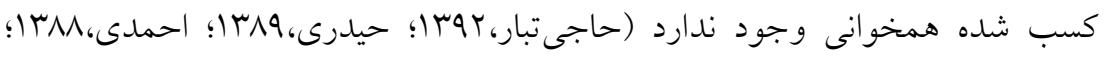

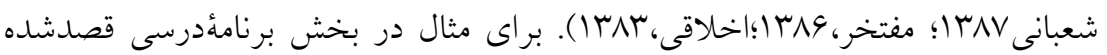

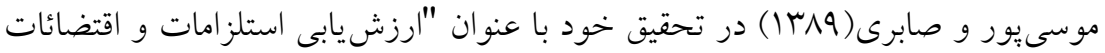

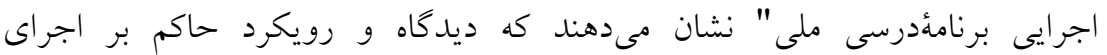

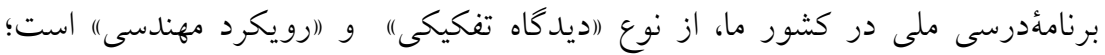

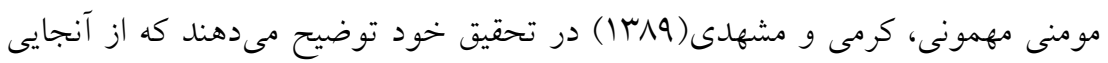
كه نظام برنامهريزى درسى در كشور ما از نوع سنتى و متمركز است، از تركيب بهينه مشاركت كنندكان در تدوين برنامهٔ درسى استفاده نمىشود؛؛ حيدرى(

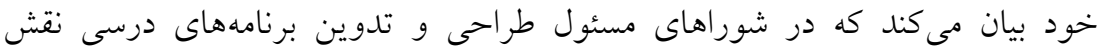

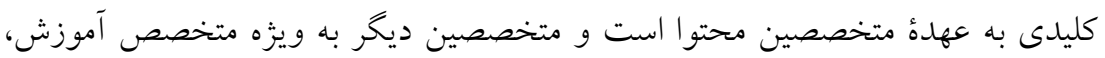
كارشناس برنامهريزى درسى كارشناس فناورى و ارزشيابى آموزشى كمترين نقش رئس را ايفا

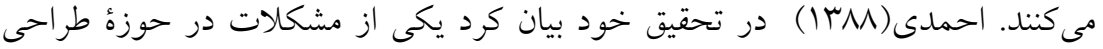
جدايى مؤلفههاى دخيل در برنامهريزى درسى يعنى جدايى دفاتر برنامهريزى و تأليف

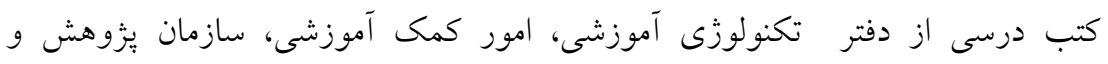

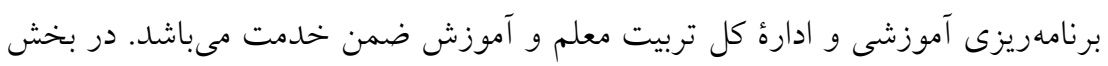
برنامdٔدرسى اجراشده و كسب شده عدم توافق و مشاركت ذى نفعان، عدم تدارى لو لوازم

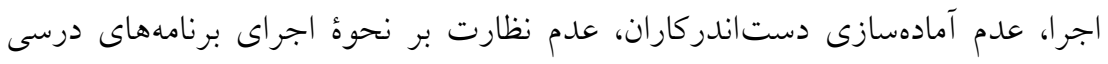

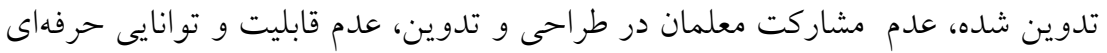

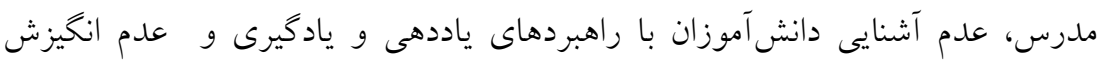

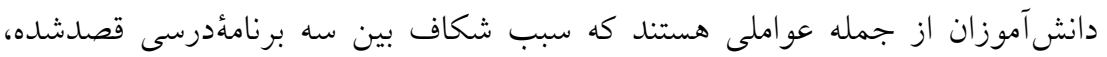

${ }^{1}$.Glatthorn, Boschee, Whitehead \&, Boschee

${ }^{2}$.Bekalo and Welford

${ }^{3}$.Menis 
طر احى و اعتبارسنجى الكَوى مفهومى كاهش فاصلة برنامذٔدرسى...

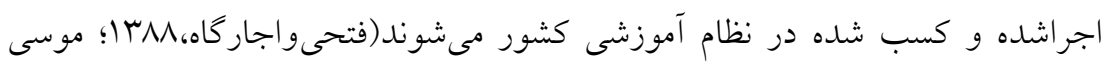

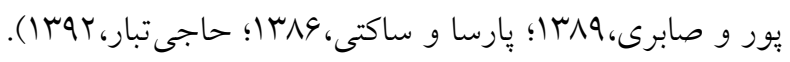

با توجه به وجود فاصله و ناهمخوانى بين سه برنامdٔدرسى ياد شده در نظام

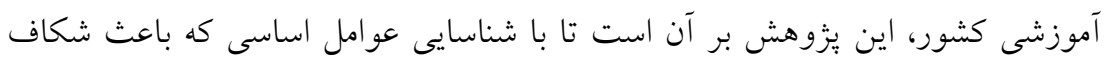

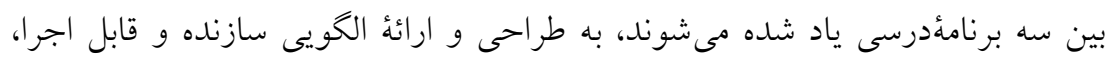

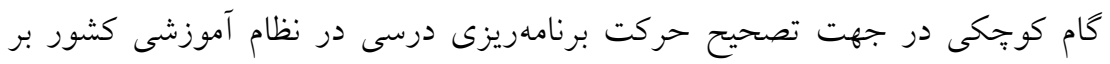

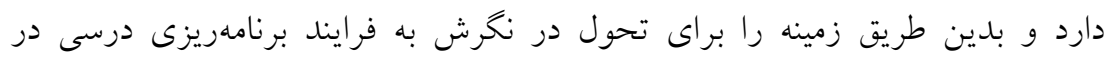

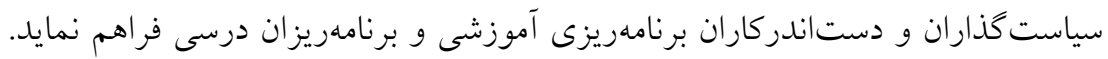

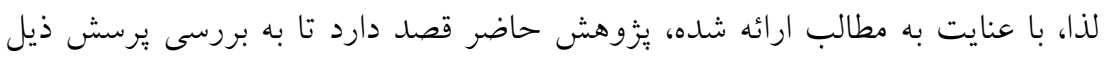
ببردازد:

1 - با جّه الكويى مى توان فاصلة بين سه برنامدٔدرسى قصدشده، اجراشده و كسبشده را كاهش داد؟ Y- الكوى ييشنهادى ارائه شده تا جهه حد معتبر است؟ روش برّوهش

روش يُزوهش تركيبى است، به طورى كه در اجراى آن روشهاى كمّى و كيفى در

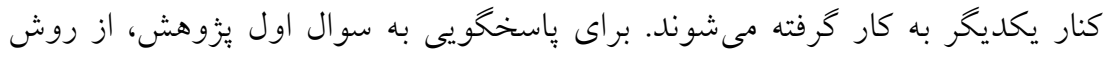

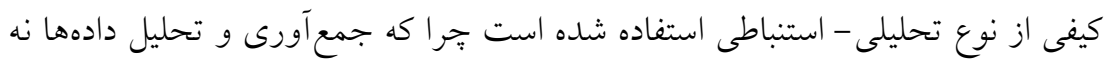

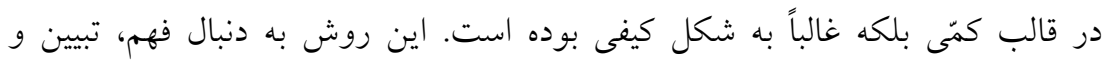
روشنساختن مجموعهاى از مفاهيم و ساختارهاى مفهومى در برنامةدرسى مىباشد.

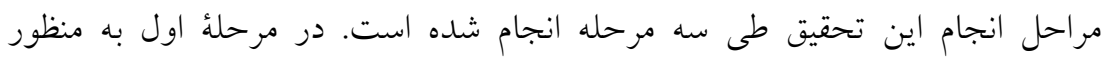
تدوين الكوى ييشنهادى از طريق بررسى و مطالعهُ بيشينهُ نظرى و يافتهاى تحقيقات

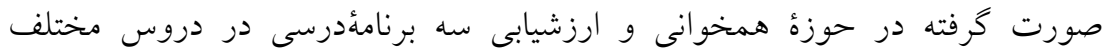

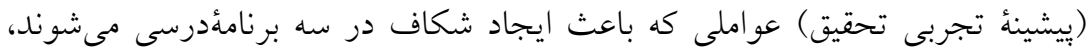

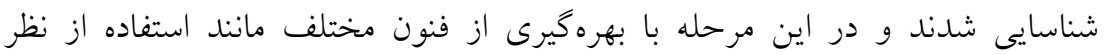


متخصصان و كارشناسان و مرور اسناد و مدارك، عواملى كه باعث شكاف در سه

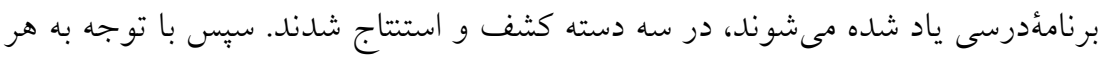
يكى از عوامل ايجاد شكاف بين سه برنامةٔدرسى ياد شده، مبانى نظرى و علمى متناسب

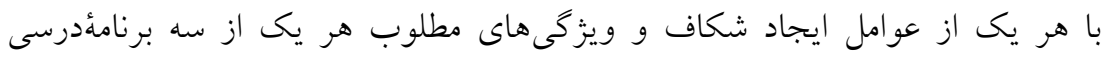

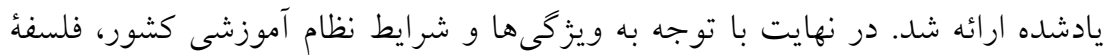
الخو، هدف، جهت گيرى، اصول و روش كاهش فاصلة بين سه برنامهٔدرسى ارائه شد.

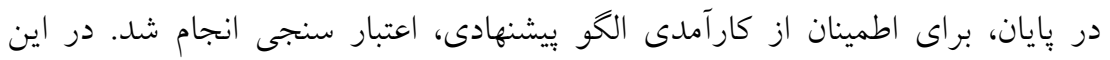

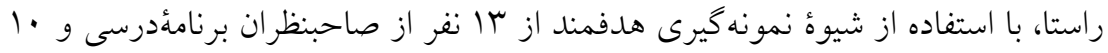

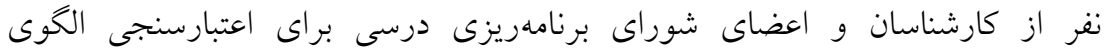

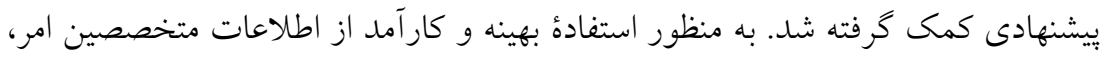
روش نمونه كيرى هدفمند در تحقيقات كيفى اجرا شده است. از اين رو تلاش شده

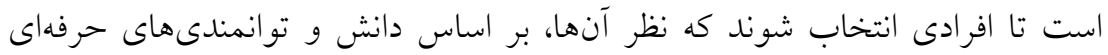

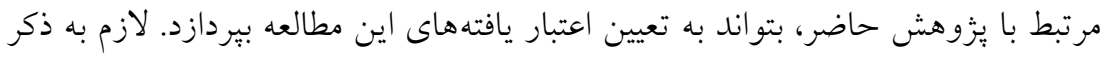

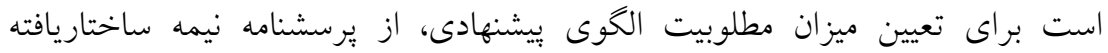
استفاده شد.

\section{يافته هاى تحقيق}

به منظور تدوين الكوى بيشنهادى براى كاهش فاصلة سه برنامdٔدرسى قصدشده،

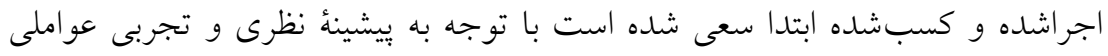

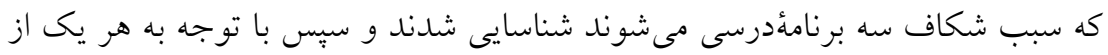

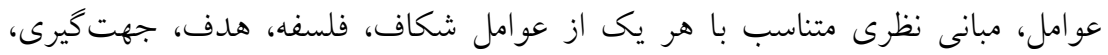

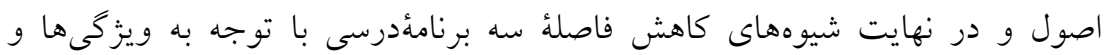

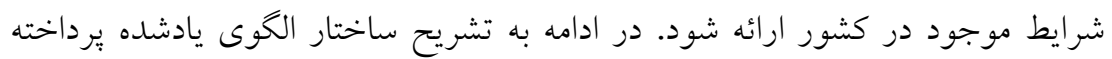
مىشود و در بايان تصوير كلى الكوى مفهومى نيز در شكل الر ارائه مى شود. عوامل اساسى ايجاد شكاف و مبانى نظرى متناسب با هريك از عوامل در حوزهٔ برنامٔدرسى قصدشده عبارتند از: 
طراحى و اعتبارسنجى الخوى مفهومى كاهش فاصلة برناملدرسى...

ا- نوع نظامبرنامهريزى درسى: نوع نظامبرنامهريزى درسى تركيب گروه تدوين كننده

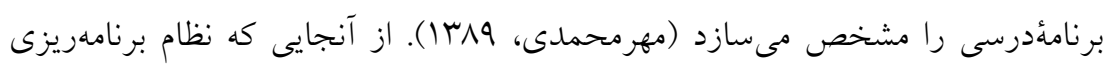
درسى در كشور ما از نوع سنتى و متمركز است، از تركيب بهينهُ مشاركت كنندكان در تدوين برنامهُ درسى (الخوى مشاركتى) استفاده نمىشود؛ به اين دليل در اين نظام فاصله بين تدوين كنند گان و مجريان و تجربه كنندگان، بيشتر مىشود. بنابراين نظامهاى برنامهريزى درسى كه توجه به انخيزهها، نيازها و تجارب دانش آموزان را به عنوان عامل اساسى در فرآيند برنامهريزى درسى مدنظر قرار دادهاند و تركيب بهينهاى از افراد را در تدوين برنامُٔ درسى به كار مى كيرند، مىتوانند ملعى هماهنكى بيشتر در بين سطوح برنامه هاىدرسى باشند.

ץ- ديدگاه حاكم بر اجراى برنامهُ درسى: بر اساس نوع ارتباط بين اقدامات برنامهريزى (طراحى، اجرا و ارزشيابى)، دو ديدگاه اجراى برنامهُ درسى به دست مى آيد؛ يكى ديدكاه تفكيكى كه در اين ديدكاه توليد، اجرا و ارزشيابى برنامهٔدرسى سه اقدام (منفك)" و (مبتنى بر هم)" هستند و تا يكى به اتمام نرسد ديخرى آغاز نمىشود. بر اساس اين ديدگاه، جداسازى دستاندركاران با عناوينى مثل برنامهريز، مجرى و ارزشياب دنبال مىشود و استقلال اين كروهها اهميت مىيابد؛ تعيين سهم و نسبت براى دستاندركاران مطرح است و انجام فعاليت موظف توسط هر يك و مجزا از يكديخر به رسميت شناخته مىشود. ديخرى ديدگاه تركيبى / وحدت گرا است كه بر اساس اين ديدكاه توليد، اجرا و ارزشيابى برنامئدرسى سه وجه يك اقداماند و جداسازى آنها در دنياى عمل (ناممكن)" و (ناكارآمد)) است. در اين ديدكاه با هم بودن همه دستاندركاران مطرح است؛ وابستخى درونى مورد نظر و عنايت است؛ ضرورت مشاركت بر همخان آشكار است و الزام به توليد ويزه (منطبق با شرايط خاص) امرى تقدير شده است

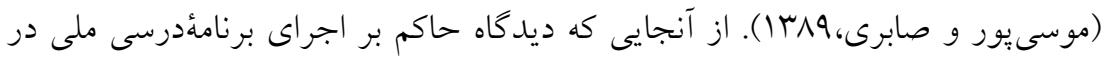
كشور ما، (ديدگاه تفكيكى) است (گر جهه اين ديدگاه داراى موافقانى است و در تاريخ برنامهريزى درسى كشورهاى مختلف سابقه زيادى دارد)، اما با محدوديتهاى زيادى از جمله "عدم انطباق با واقعيت" و "فاصلهُ بين توليد و اجراى برنامهٔدرسى" همراه است؛ 
اين امر باعث افزايش شكاف بين تدوينكندكان و مجريان و تجربهكنندكان مىشود.

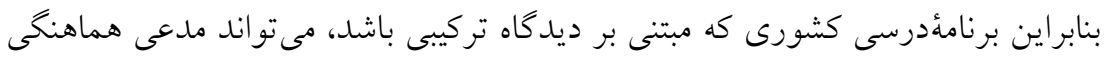
بيشتر سطوح برنامهاى درسى باشد.

r- رويكرد حاكم بر اجراى برنامةٔدرسى: از حيث نوع مواجهؤ برنامةدرسى با مردم، دو رويكرد اجراى برنامdدرسى بديد مى آيد؛ يكى رويكرد تربيتى كه در اين رويكرد برد

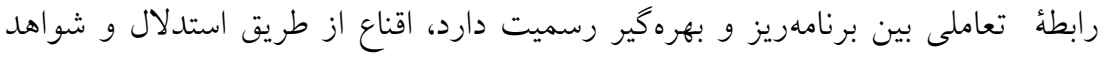

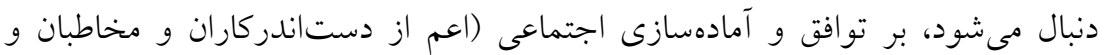

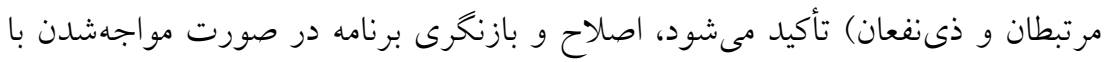

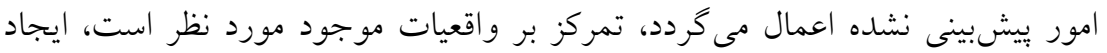

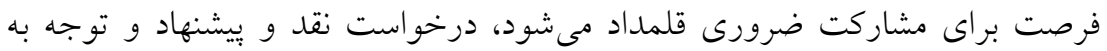
اقتضائات اجرايى ديده مىشود. رويكرد تربيتى با اطلاعرسانى صادقانه به اشخاص و و

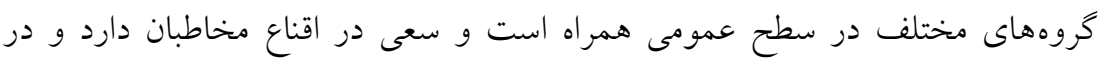

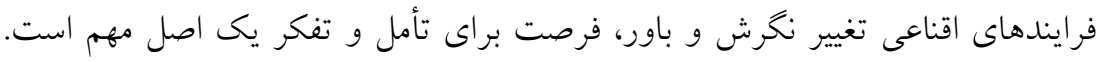

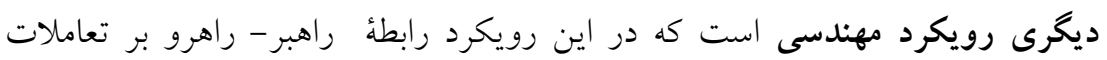

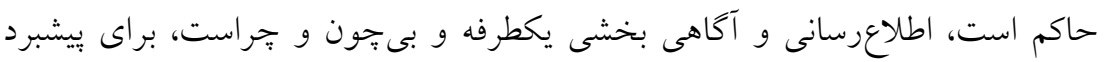

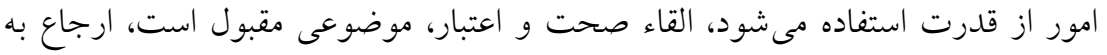

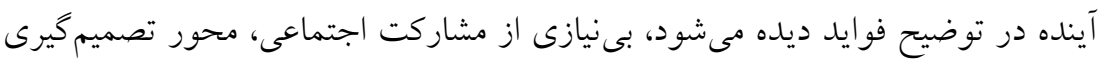

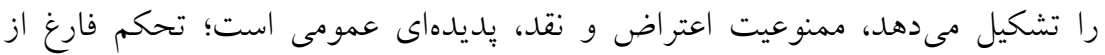

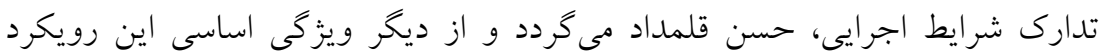

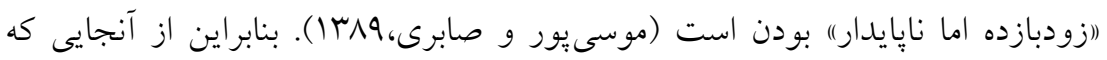

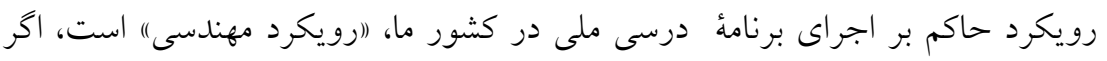

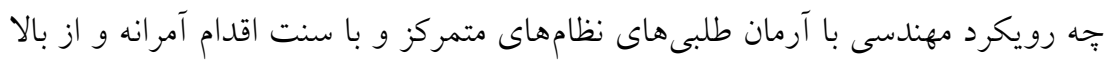

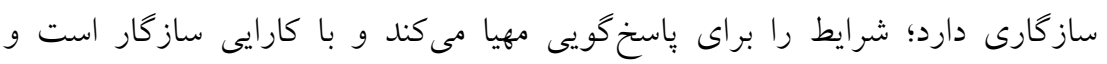

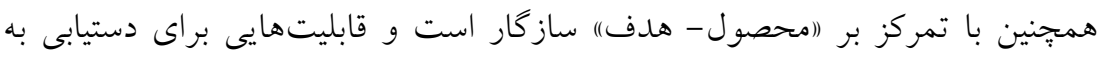


طراحى و اعتبارسنجى الكوى مفهومى كاهش فاصلة برنامdٔدرسى...

استانداردها دارد، اما با وجود اين مسائل، اين رويكرد به تحقق امور از ييشتعيين شده نظر دارد و جايى براى (شدن)) و (روييدن)) اختصاص نمىدهد. در اين رويكرد، امور مقدر شدهاند؛ بنابراين، جايى براى (انتخاب) و (اخلاقيت)) ديده نشده است. همختين به كاركيرى اين رويكرد " مانع مشاركت ذىنفعان" است اين امور سبب ايجاد فاصله بين سطوح برنامdٔدرسى مىشود. بنابراين نظامهاى برنامهريزى درسى كشورى كه رويكرد حاكم بر اجراى برنامهُ درسى آن رويكرد تربيتى باشد، سبب هماهنگى بيشتر در سطوح برنامdٔدرسى مىشود.

F- تخصص محورى در حوزة طراحى و تدوين برنامه درسى: در شوراهاى مسئول طراحى برنامههاى درسى نقش كليدى به عهدة متخصصين محتواست و متخصصين ديخر به ويزه متخصص آموزش، كارشناس برنامهريزى درسى، كارشناس فناورى و ارزشيابى آموزشى كمترين نقش را ايفا مى كنند (حيدرى،ور؟|). با توجه به اين موضوع هر جهه مشاركت متخصصين آموزش، برنامهريزى درسى، فناورى و مشاركت ذىنفعان در طراحى برنامهريزى درسى بيشتر باشد، هماهنخى سطوح برنامهٔدرسى بيشتر مىشود.

ه- جدايى مؤلفه هاى دخيل در برنامهريزى درسى: به علت جدايى مؤلفههاى دخيل در برنامهريزى درسى يعنى جدايى دفاتر برنامهريزى و تأليف كتب درسى از دفتر تكنولوزى آموزشى، امور كمى آموزشى، سازمان يزوهش و برنامهريزى آموزشى و اداره كل تربيت معلم و آموزش ضمن خدمت و همجنين دفتر ارزشيابى تحصيلى، عملاً هماهنگى لازم بين دفاتر برنامهريزى و تأليف كتب درسى با اين دفاتر دجار مشكل مى شود. معمولاً نمايندكان دفاتر مذكور در شوراهاى برنامهريزى درسى حضور ندارند و تنها يُ از توليد برنامهُ درسى است كه از اين دفاتر انتظار مىرود در ساخت و توليد ضمايم برنامه (مانند كتابهاى كمك درسى، فيلمهاى آموزشى و ...) اقدام نمايند

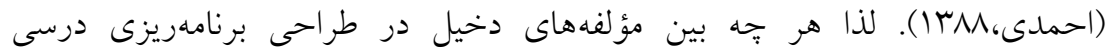
هماهنخى بيشترى باشد، منجر به هماهنخى بيشتر سطوح برنامdٔدرسى مىشود. عوامل موثر بر كاهش فاصلة بين سه برنامهٔدرسى در حوزهُ برنامهٔدرسى اجرا شده 
1- ماهيت برنامٔدرسى تدوين شده: ماهيت هر برنامهٔدرسى كه با جهار ويزّى (انياز

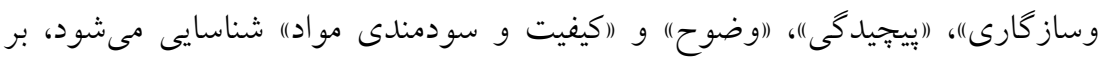

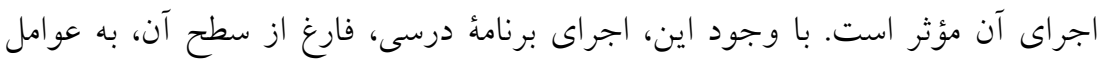

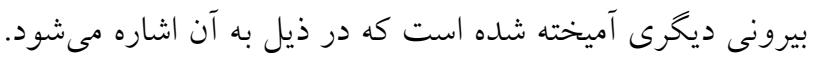
r r r r بوامل بيرونى

r, I, كسب توافق و مشاركت ذيىنفعان. مىتوان شاهد توفيق يك برنامه بود كه

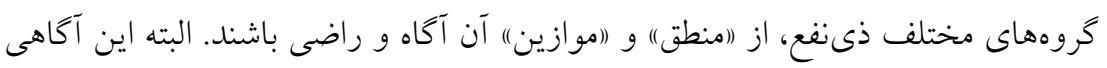

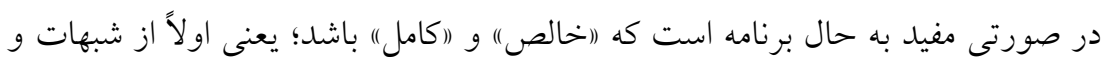

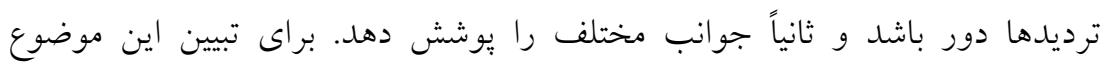

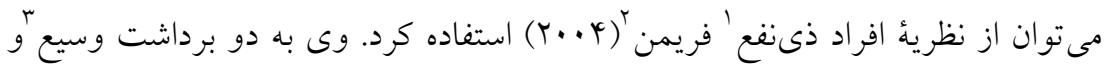

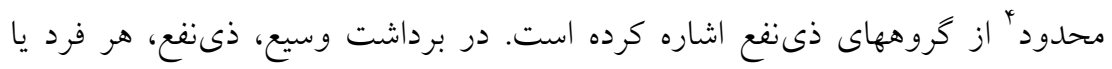

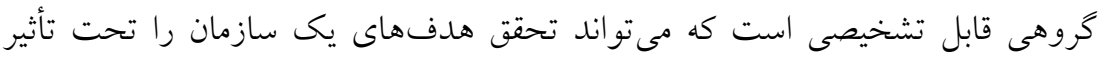

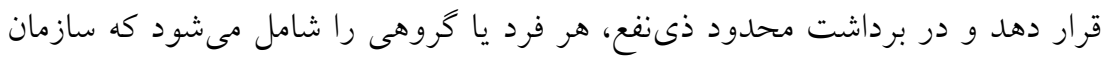

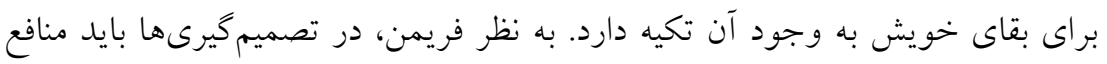

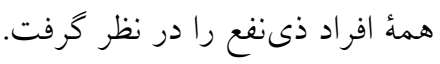

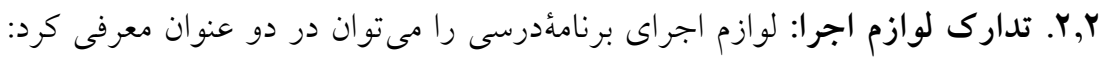

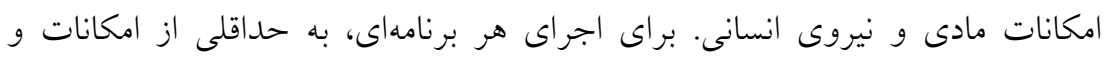

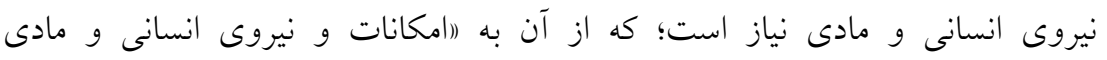

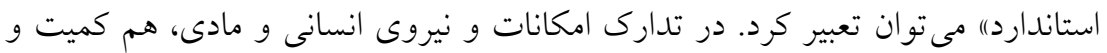

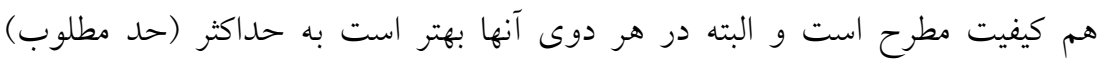
دست يافت؛ هر جند كه در شروع نبايد از حداقل (حد استاندارد) فروتر آمد.

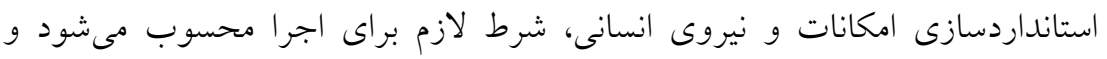

\footnotetext{
${ }^{1}$.Stakeholder theory

${ }^{2}$.Freeman

${ }^{3}$. The Wide sense of stakeholder

${ }^{4}$.The narrow sense of stakeholder
} 
طر احى و اعتبارسنجى الكَوى مفهومى كاهش فاصلة برنامذٔدرسى...

بدون آن اجرا به انحراف مىرود؛ هر جند كه كاه اجراى برنامهٔ درسى بدون جنين شر ايطى هم آغاز مى شود.

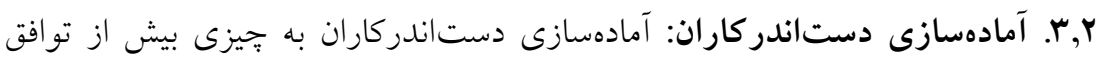

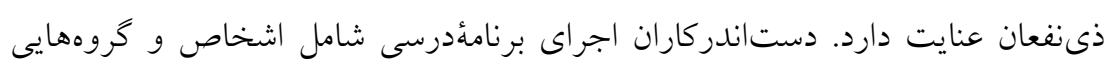

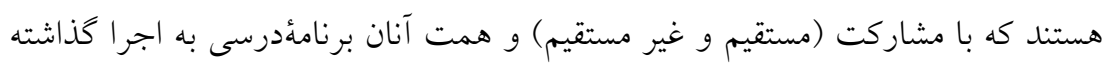

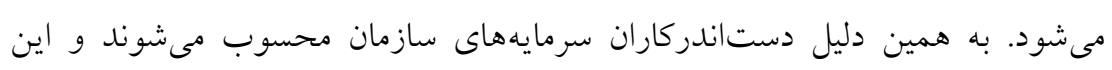

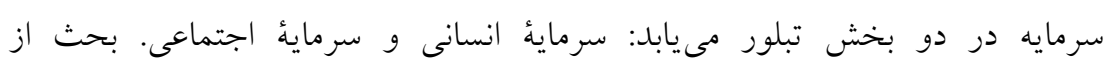

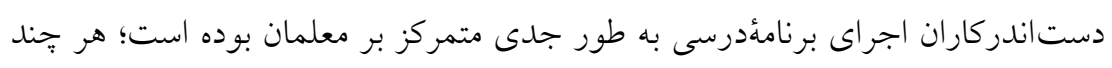

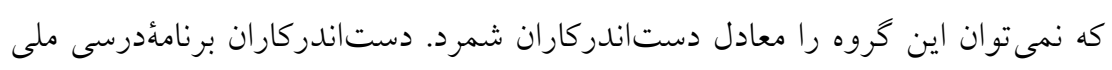

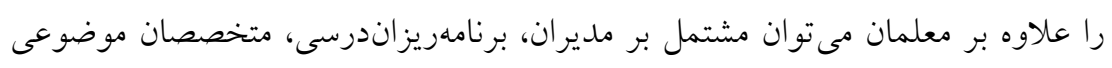

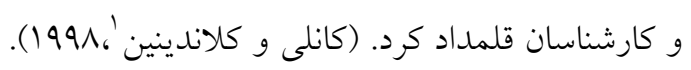

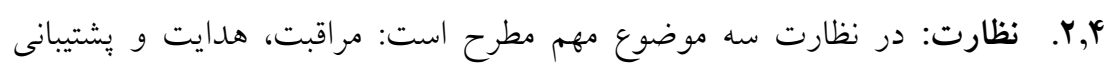

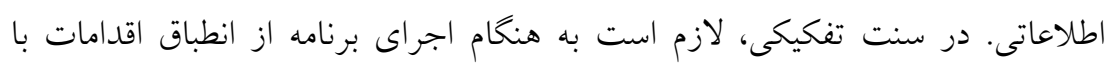

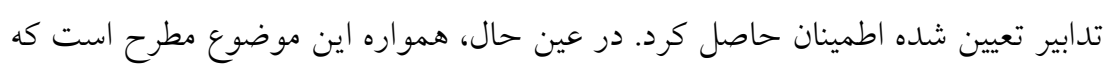

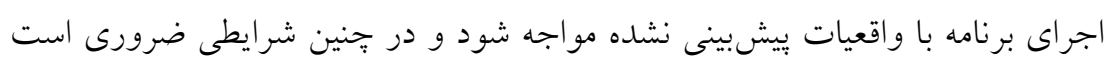

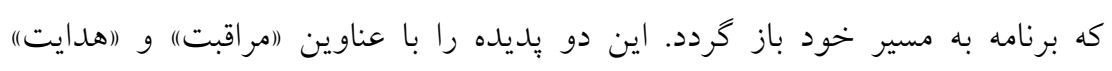

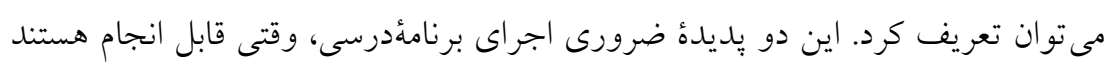

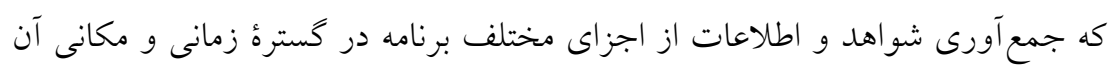

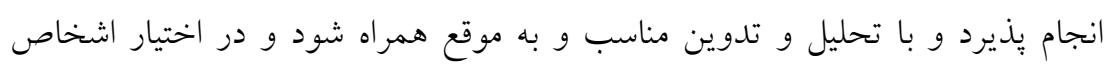
ذنىربط قرار گيرد.

1. Schwab 


\section{عوامل مرتبط با معلم}

r, ا. مشاركت معلمان: شوآب' (19Vr) مدرس را عضو اصلى گروههاى تصميمكَيرندة برنامة درسى به حساب مى آورد. مدرسان محور اصلى فعاليتهاى برنامهريزى

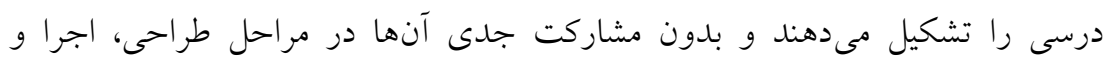

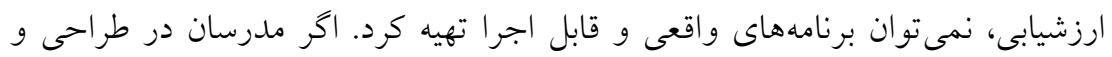

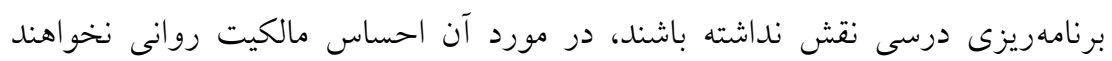
كرد؛ همجنين مشاركت مجرى در فرايند تدوين برنامdدرسى اثربخشى و كارايى برنامةٔ-

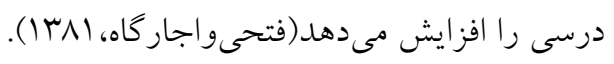

r.r.

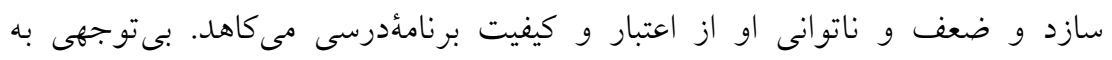

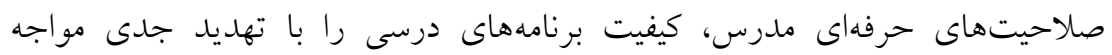

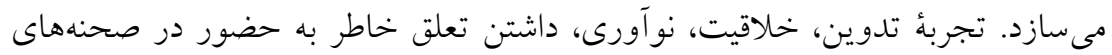

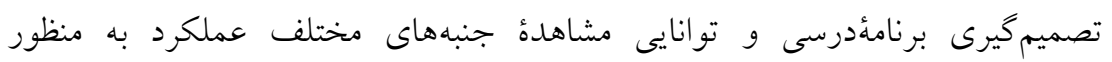

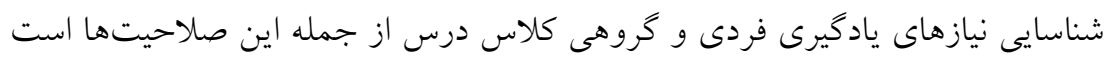

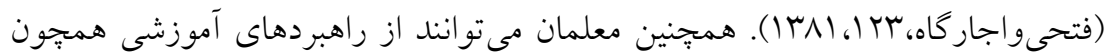

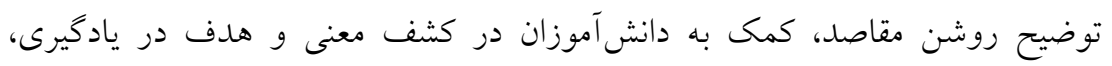

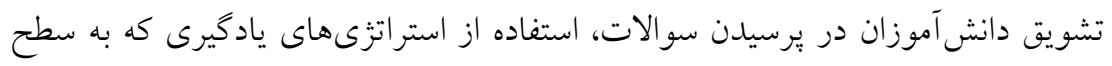

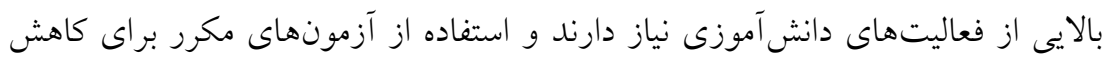

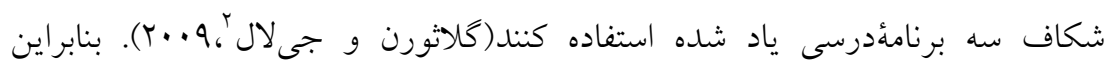

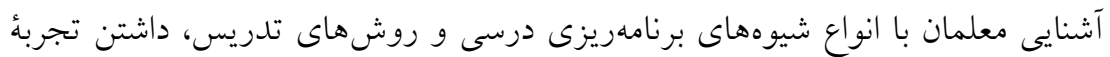

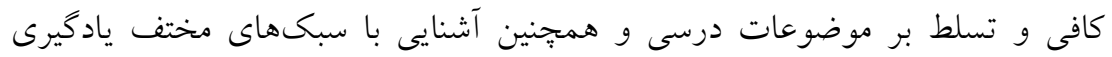

${ }^{1}$.The Wide sense of stakeholder

${ }^{2}$.Jailall \& Glatthorn 
طر احى و اعتبارسنجى الكَوى مفهومى كاهش فاصلة برنامذٔدرسى...

دانشآموزان موجبات موفقيت برنامdدرسى قصد شده و هماهنكى برنامههاى درسى ياد

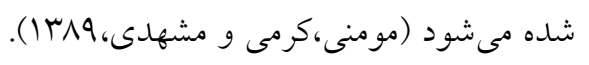

\section{عوامل موثر بر كاهش فاصلة سه برنامئدرسى در بخش برنامٔدرسى كسب شده}

1- آمادگى يادگيرنده: آمادگى يادگيرنده براى يادگيرى هدفهاى آموزشى بسيار مهم

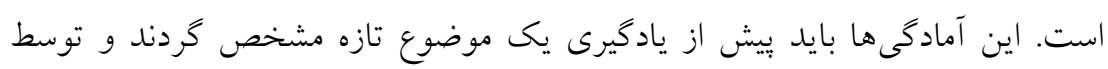

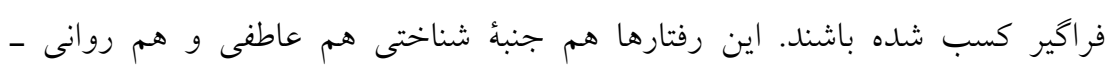

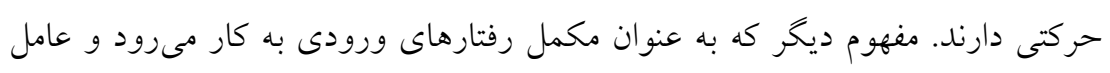

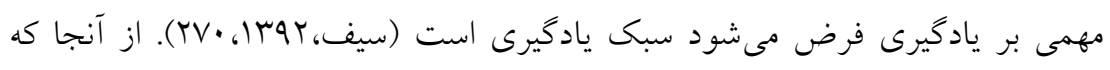

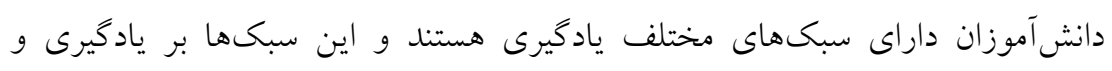

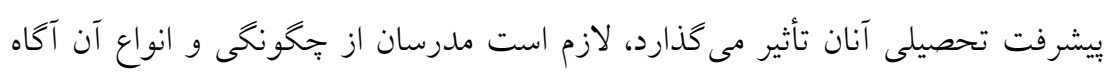

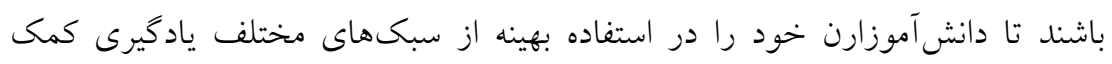
كنند.

ץ- آشنايى يادگيرنده با راهبردهاى يادگيرى: تفسير فراخيران از محيط يادكيرى و

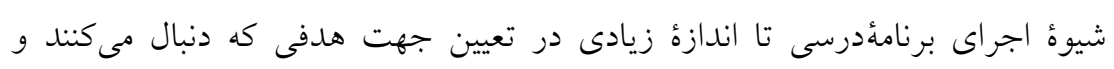

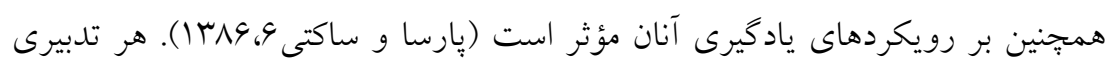

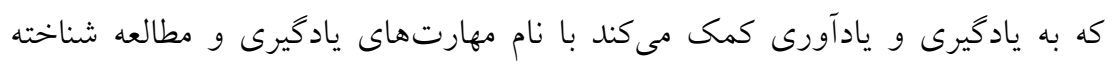

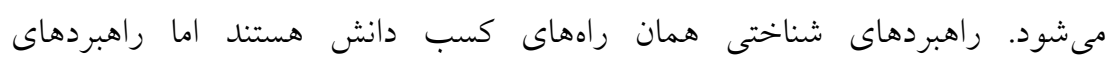
فراشناختى تدابيريى هستند براى نظارت بر راهبردهاى شناختى و كنترل و هدايت هنان آنان رهان

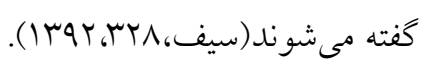

r- انغيزش دانش آموزان: بارها دانشآموزانى را ديدهايم كه از لحاظ توانايى و استعداد

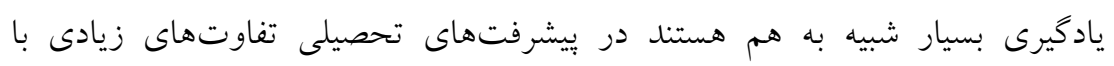

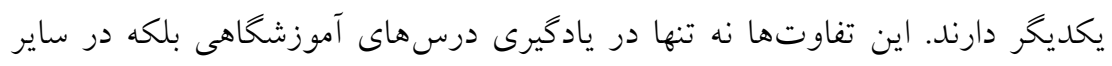


فعاليتهاى غير تحصيلى نيز به جشم مىخورد. اين جنبه از رفتار دانشآموز به حوزه

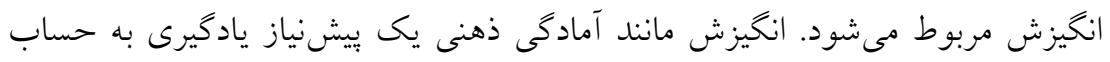

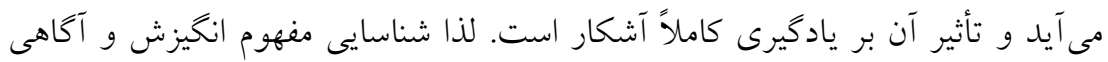

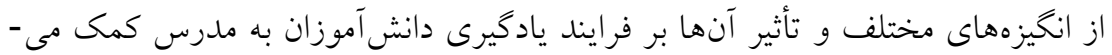

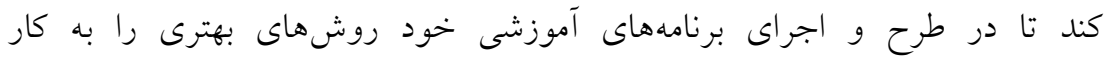

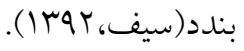

\section{r. - ملسفة الكو}

منظور از فلسفةُ الكو اشاره به جيستى و جهرايى آن است، يعنى مشخص مى كند كه اولاًا

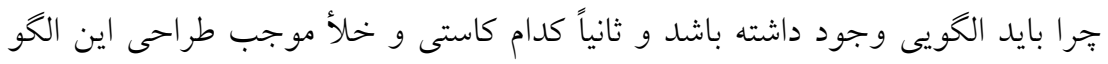
شده است. فلسفهُ وجودى الكوى مورد نظر موارد زير مىباشد:

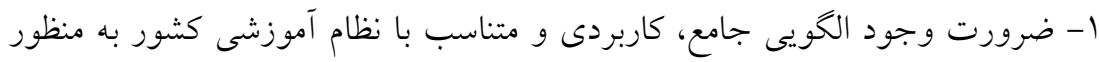

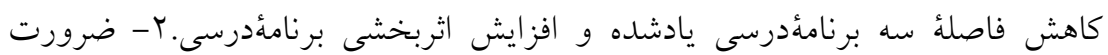

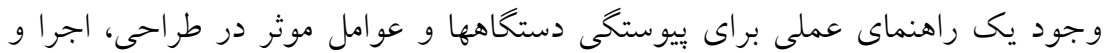

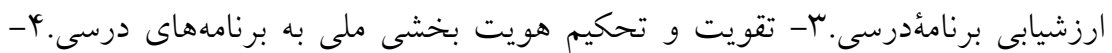

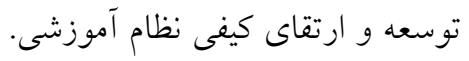

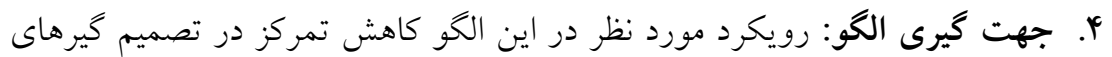
فرايند برنامهريزى درسى خصوصاً طراحى و توليد مواد آموزشى است.

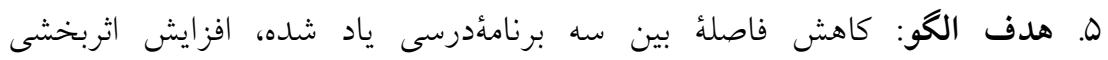
برنامأدرسى و افزايش بيشرفت تحصيلى.

\section{9. اصول الكو براى رسيدن به هدفها}

1- اصل مشاركت ذى نفعان: به مشاركت ذئنعان (معلمان، برنامهريزان، سياستخذاران،

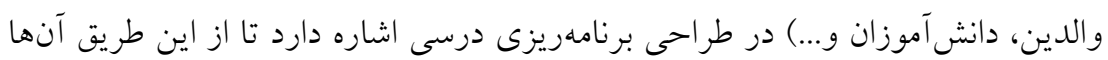

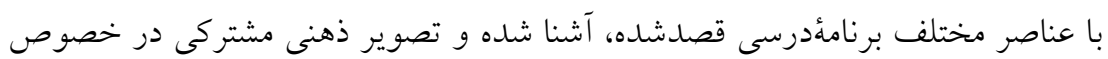

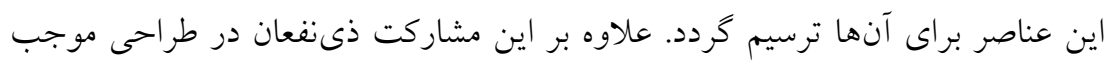


طر احى و اعتبارسنجى الكَوى مفهومى كاهش فاصلة برنامذٔدرسى...

افزايش تعهد آنها در اجراى برنامٔدرسى و در نتيجه افزايش اثربخشى برنامهدرسى مى كردد.

ץ- اصل همكارى ذى نفعان و مؤلفههاى دخيل در برنامهددسى: وقتى كه گروههاى

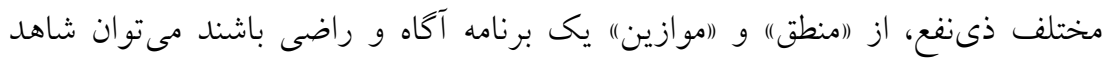

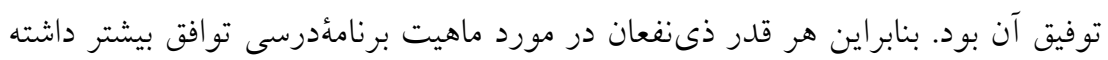

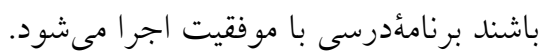

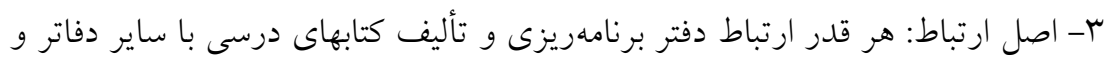

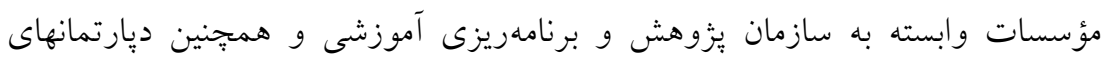

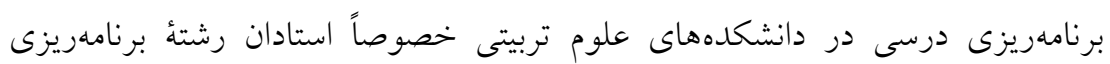
درسى بيشتر باشد فاصله سه برنامئدرسى كمتر مى شود.

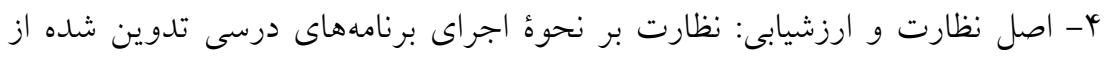

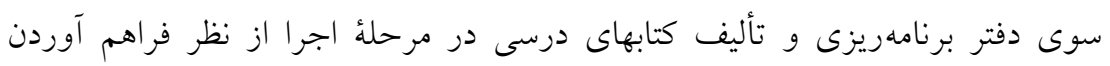

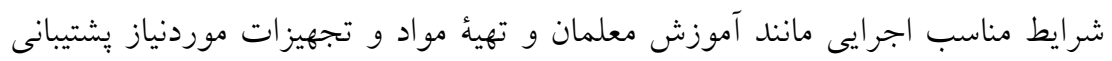
و غيره سبب كاهش فاصلة سه برنامؤدرسى مىشود.

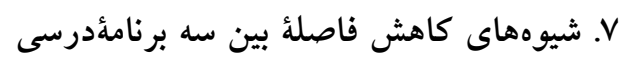

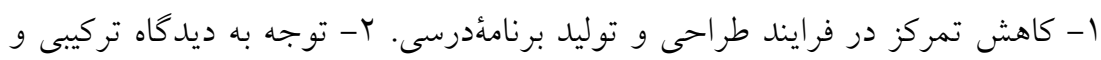

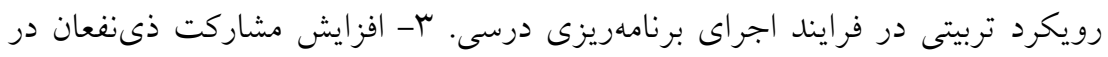

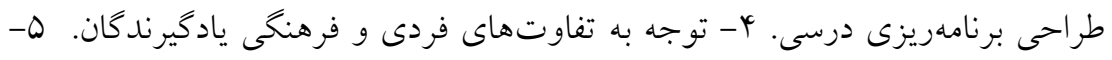

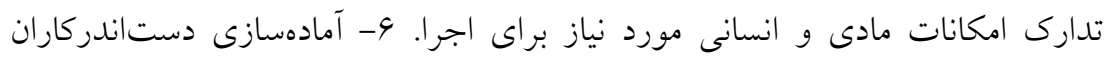
فرايند برنامهريزى درسى. V- افزايش قابليتها حرفهاى معلمان. ^- توافق مولفههاى دخيل در فرايند برنامهريزى درسى. 9- افزايش نظارت بر اجراى فرايند برنامهريزى درسى از سوى دفتر برنامه ريزى و تأليف كتابهاى درسى. • ل- تربيت كارشناسان

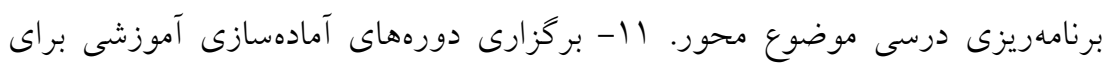

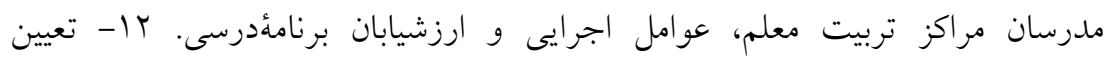


دو فصلنامهُ نظريه و عمل در برنامهٔ درسى، شماره V، سال جهارم، بهار و تابستان هب11

استانداردهاى مناسب براى تشخيص ميزان موفقيت يك برنامٔدرسى در فرايند ارزشيابى.

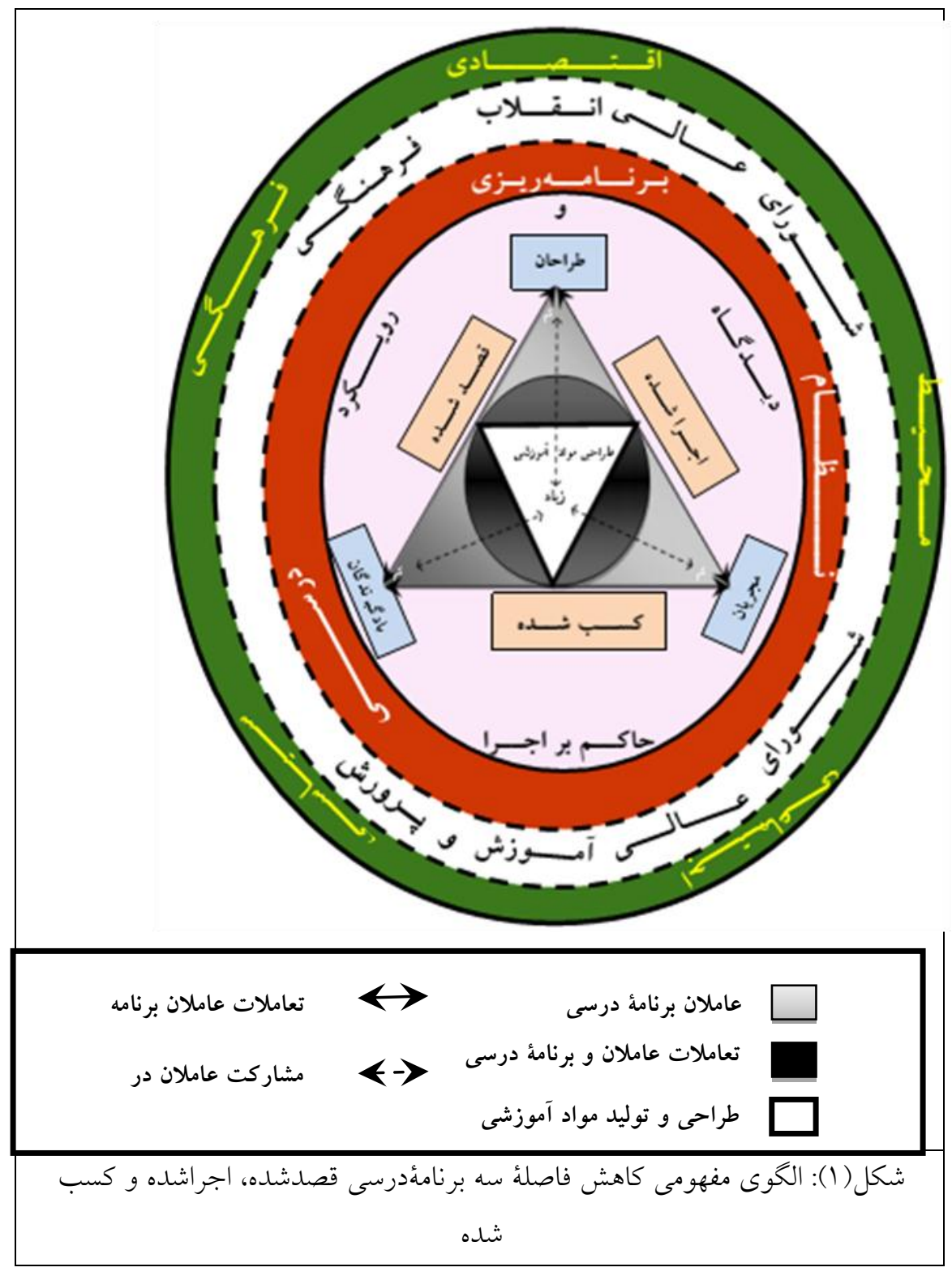


طر احى و اعتبارسنجى الكَوى مفهومى كاهش فاصلة برنامذٔدرسى...

شكل (1) نشان دهنده الكوى مفهومى كاهش فاصلة سه برنامهٔدرسى ياد شده است

كه متشكل از جهار قسمت دايرهاى شكل است.در قسمت مركزى شكل ديدكاه و

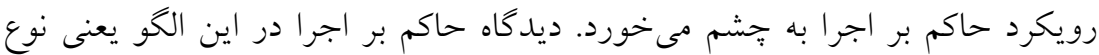

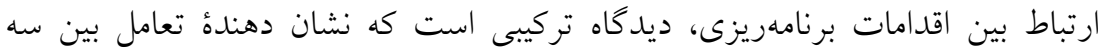
برنامٔدرسى است و رويكرد حاكم بر اجرا، رويكرد تربيتى است كه در نتيجه هنين

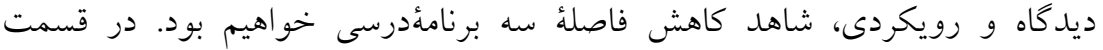
مركزى شكل، ارتباط سه نوع برنامؤدرسى از دو منظر قابل شرح است: اول اينكه

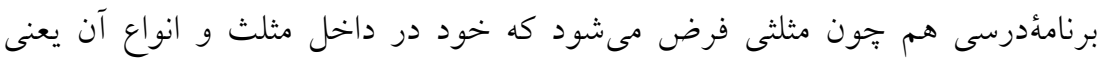

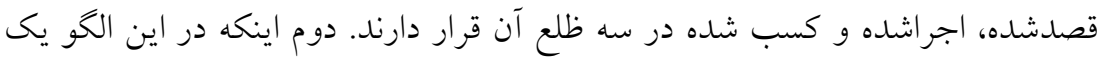

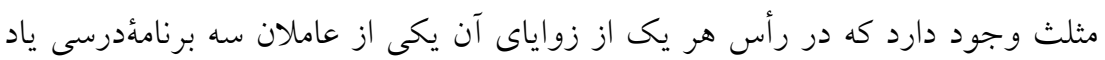

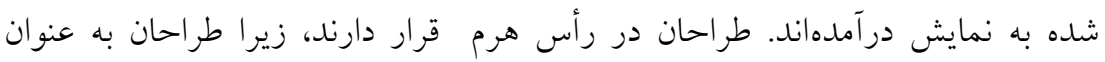

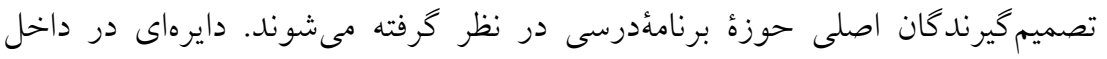

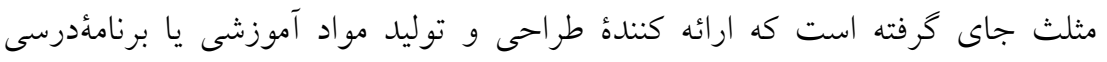

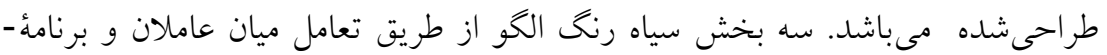

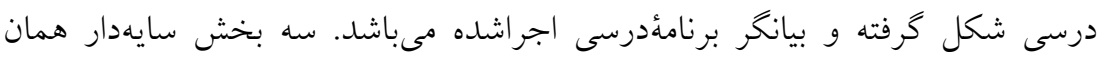

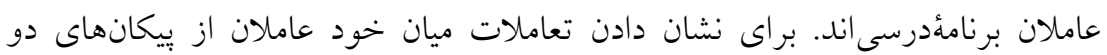
جهتى در سه طرف مثلث استفاده شده است. در اين تصوير يبوستارى كه مشاركت

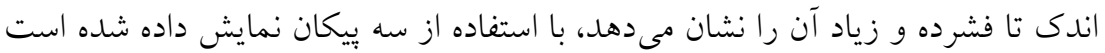

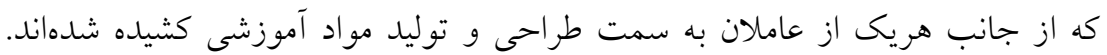

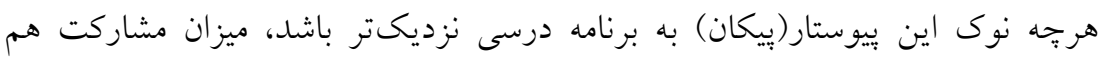
بيشتر خواهد بود.

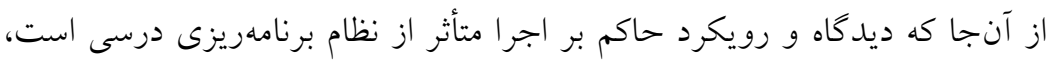

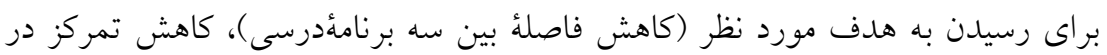

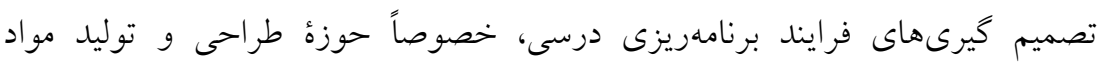

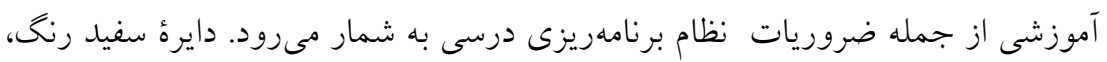


شامل شوراى انقلاب فرهنگى و شوراى عالى آموزش و يرورش است كه با تدوين

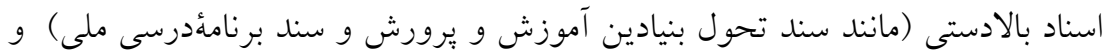

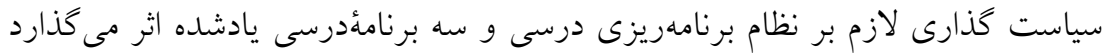

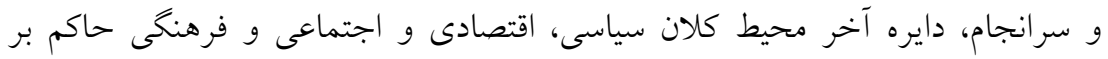

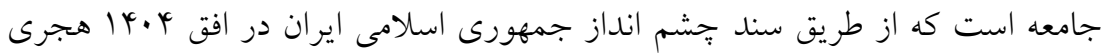

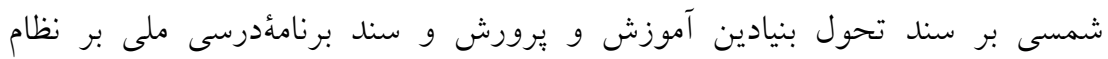
برنامهريزى درسى و سه برنامdٔدرسى يادشده اثر مى كذارد.

\section{Y- الكوى بيشنهادى ارائه شده تا جه حد معتبر است؟}

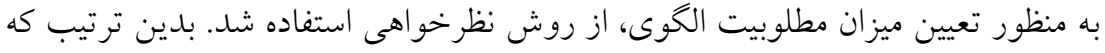

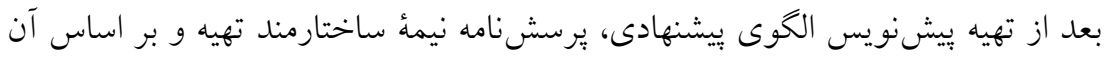

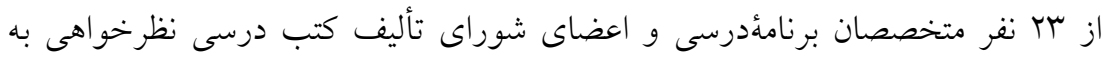

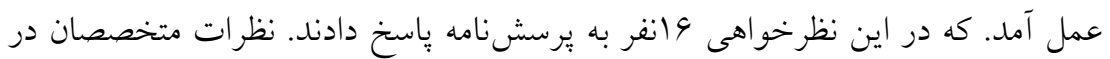

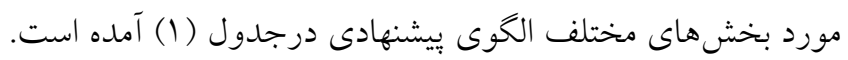
جدول (1): ديدكاه متخصصان در مورد مطلوبيت الكو مجنو

\begin{tabular}{|c|c|c|c|c|c|c|c|c|}
\hline \multicolumn{2}{|c|}{ 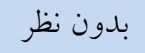 } & \multicolumn{2}{|c|}{ مخالف } & \multicolumn{2}{|c|}{ 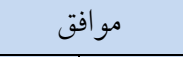 } & \multirow{2}{*}{\multicolumn{3}{|c|}{ 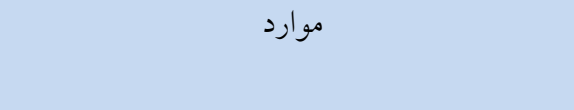 }} \\
\hline 2 & ف & 2 & ف & 2 & ف & & & \\
\hline & & $4, r$ & 1 & $4 r, \wedge$ & 10 & \multicolumn{2}{|c|}{ 1- نوع نظامبرنامهريزى درسى } & \\
\hline & & $4, r$ & 1 & $9 \mu, \wedge$ & 10 & \multicolumn{2}{|c|}{ r- ديدكاه حاكم بر اجرا } & عو امل \\
\hline $9, r$ & 1 & $4, r$ & 1 & $\wedge \vee, \Delta$ & 14 & \multicolumn{2}{|c|}{ r- رويكرد حاكم بر اجرا } & شكاف در \\
\hline $4, r$ & 1 & $1 Y, \Delta$ & r & $\Lambda 1, r$ & Ir & \multicolumn{2}{|c|}{ طر احى - تخصص محورى در حوزه } & بر بامة \\
\hline $4, r$ & 1 & $4, r$ & 1 & $\Lambda \mathrm{V}, \mathrm{\Delta}$ & 14 & \multicolumn{2}{|c|}{ بر بامهريزى درايى مؤلفه هاى دخيل در } & ق قصدشده \\
\hline $4, r$ & 1 & $4, r$ & 1 & $\wedge \vee, \Delta$ & 14 & \multicolumn{2}{|c|}{ ماهيت برنامdٔدرسى تدوين شده } & \multirow{4}{*}{ شكاف درامل } \\
\hline & & $9, r$ & 1 & $q \mu, \wedge$ & 10 & ذع عدم توافق و مشاركت & \multirow{3}{*}{ 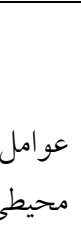 } & \\
\hline & & & & $1 \cdots$ & 19 & عدم تدارك لوازم اجرا & & \\
\hline & & $4, r$ & 1 & $4 r, \wedge$ & 10 & عدم آمادهسازى & & \\
\hline
\end{tabular}


طراحى و اعتبارسنجى الخوى مفهومى كاهش فاصلة برنامٔدرسى...

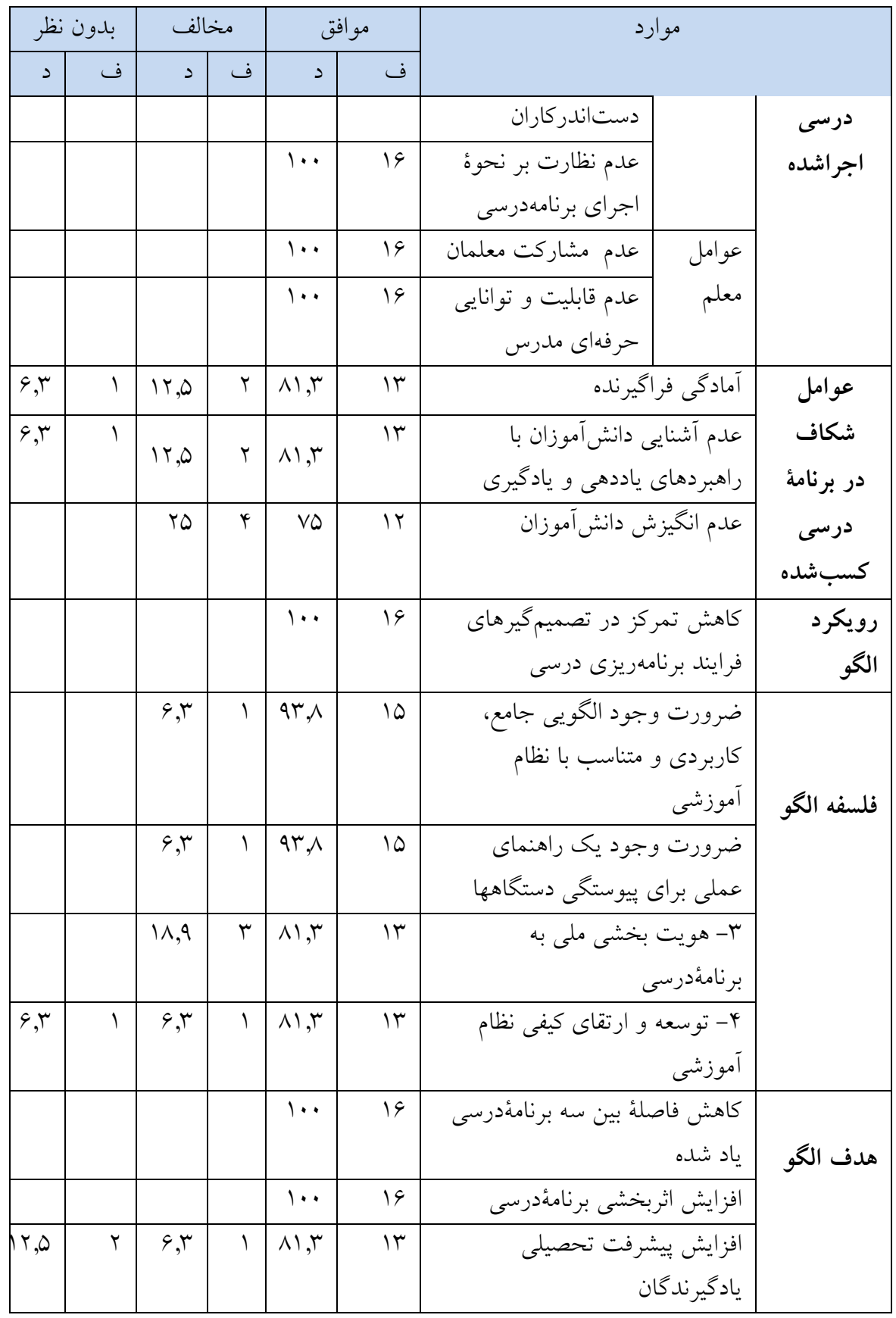


دو فصلنامه نظريه و عمل در برنامهٔ درسى، شماره V، سال جهارم، بهار و تابستان هوس|

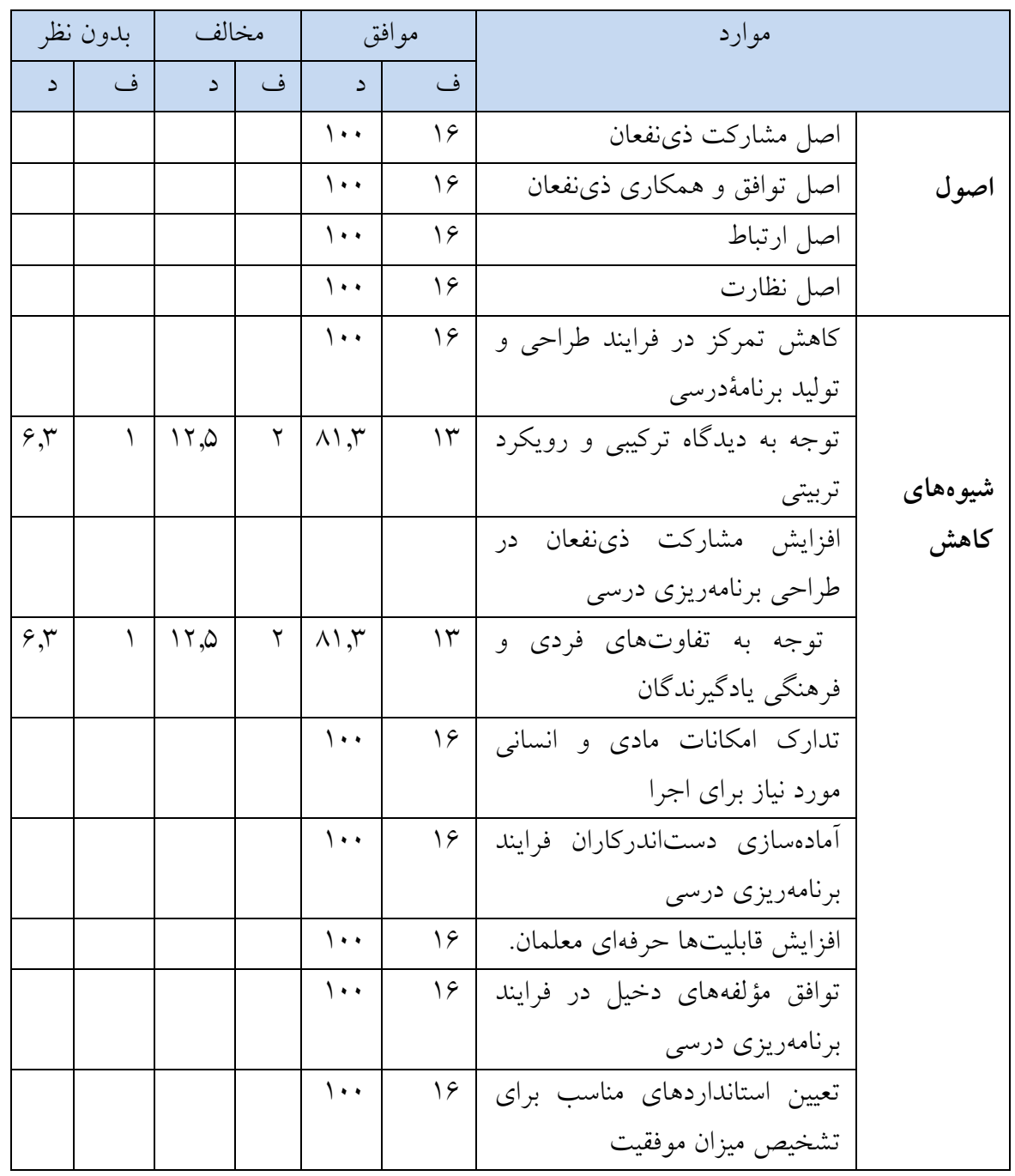

\section{بحث و نتيجه گيرى}

با توجه به مبانى نظرى و تجربى تحقيق مىتوان اينگونه اظهار داشت كه ايجاد شكاف بين سطوح برنامdٔدرسى، امرى طبيعى است و هر سه عامل تدوين كننده، مجرى و تجربه كننده (دانشآموز) در اين امر تأثير كذار هستند. آنجه اهميت دارد اين است كه 
طر احى و اعتبارسنجى الكوى مفهومى كاهش فاصلة برنامذٔدرسى...

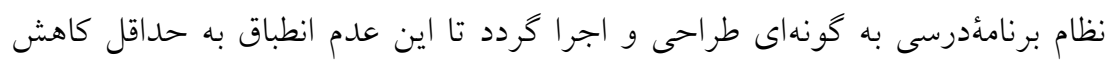

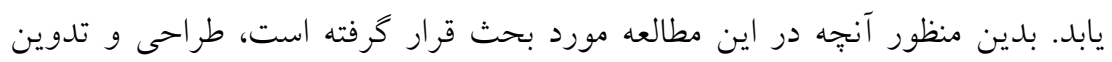

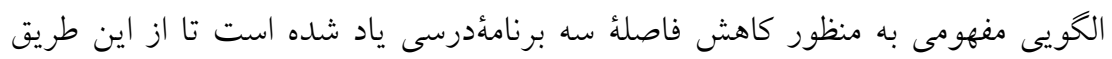

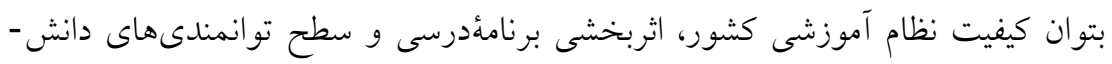

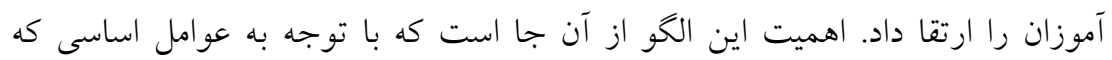

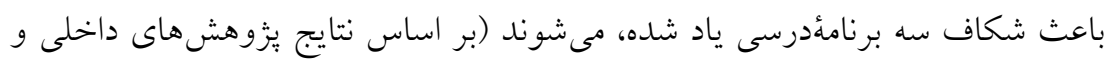

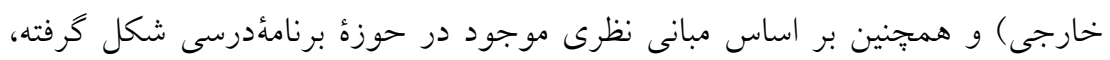

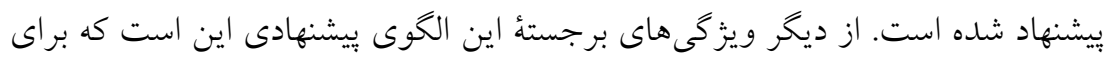

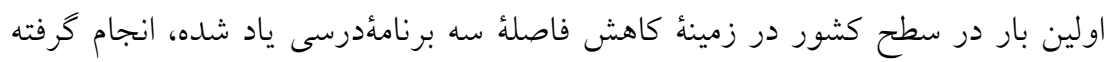

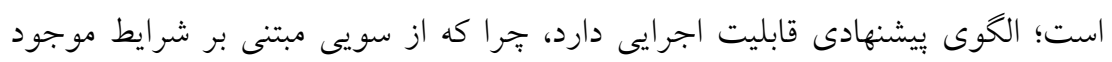

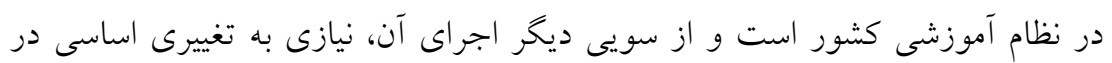

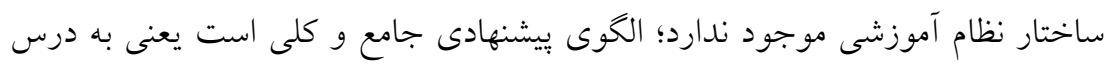

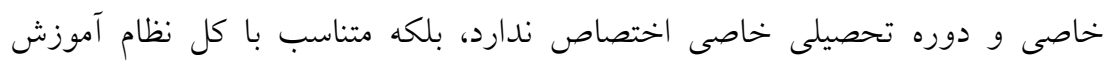

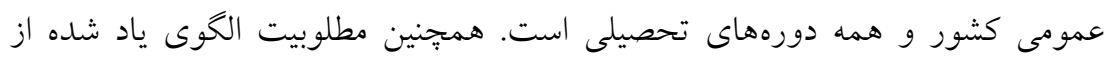

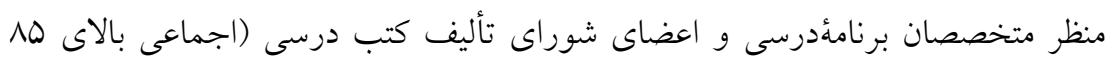

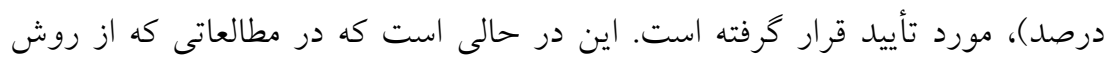

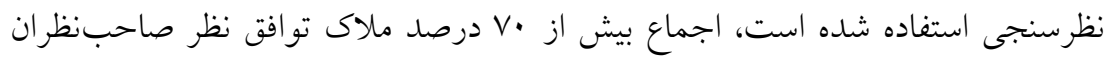

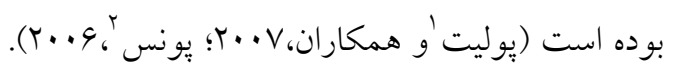

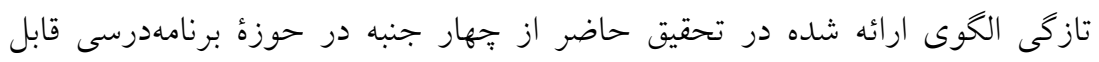

$$
\text { بحث و بررسى است: }
$$

(1) در نظر كرفتن سه مورد از عاملان (ذىنفعان) برنامؤدرسى (يعنى طراحان، مجريان

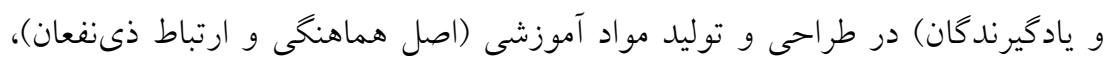

\footnotetext{
${ }^{1}$.Polit

2. Pons
} 
در حالى كه در نظام آموزشى كشورمان معمولاً طراحان به تنهايى مورد توجه قرار مى گيرند.

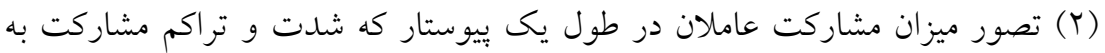
ميزان اندك تا نوع بسيار آن را منعكس مى منمايد. جنين ديدكاهى در خصوص مش مشاركت، اين فرصت را ايجاد مى كند كه متخصصان برنامئدرسى در سطحى فراتر از سنجش و و

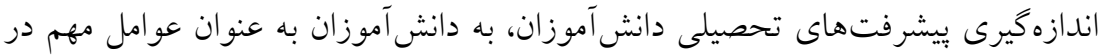
برنامهدرسى نخاه كنند. جنين پييوستارى با دارا بودن تراكم مشاركتى اندى تا زياد، بينشهاى خالص و فرهيختهاى را در درى اثر ذىنفعان در طراحى برنامهدرسى فراهم

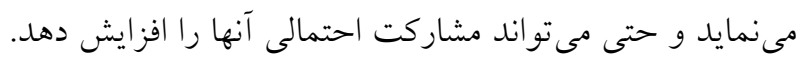
(r) تفاوت ميان مشاركت اندى و زياد هر يكى از عاملان، سوالات تحقيقاتى را به

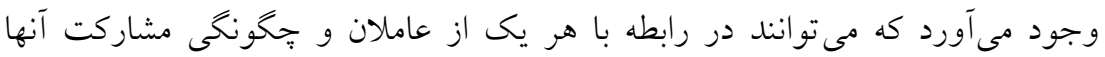

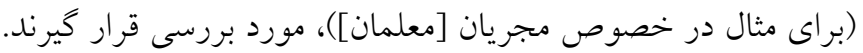

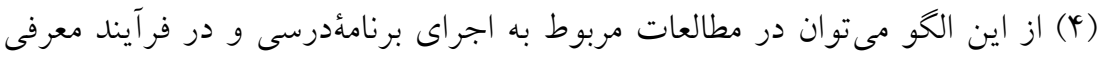
برنامهريزان، طراحان و مجريان قلمرو برنامdٔدرسى استفاده كرد.

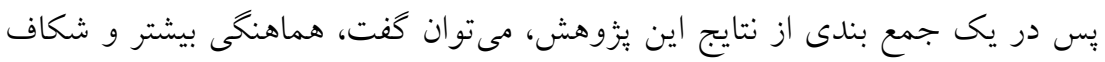
كمتر در بين سطوح برنامههاى درسى، با امعان نظر به موارد زير محقق خواهد شاند:

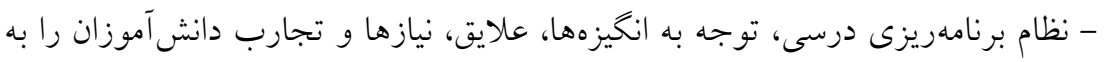

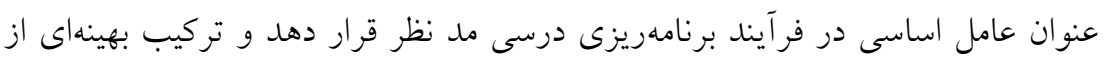
افراد را در تدوين برنامdٔدرسى به كار گيرد.

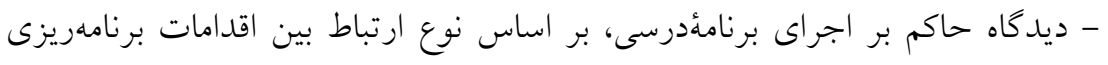

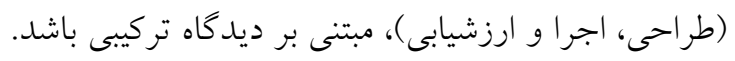

- رويكرد حاكم بر اجراى برنامdٔدرسى از حيث نوع مواجهة برنامdٔدرسى با مردم، رويكرد تربيتى باشد. 
طر احى و اعتبارسنجى الكوى مفهومى كاهش فاصلة برنامذٔدرسى...

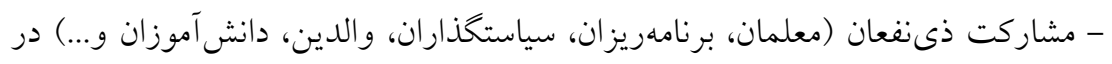
طراحى و تدوين برنامهريزى درسى، خصوصاً طراحى و توليد مواد آموزشى بيشتر باشد.

- بين ذىنفعان و مؤلفههاى دخيل در طراحى و تدوين برنامهريزى درسى، هماهنكى وتعامل بيشترى باشد. - ارتباط دفتر برنامهريزى و تأليف كتابهاى درسى با ساير دفاتر و مؤسسات وابسته به به بهاته

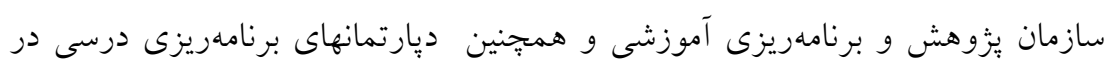

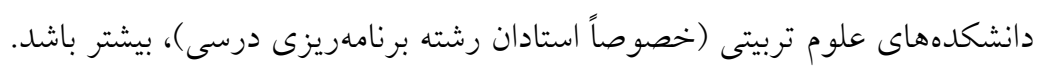

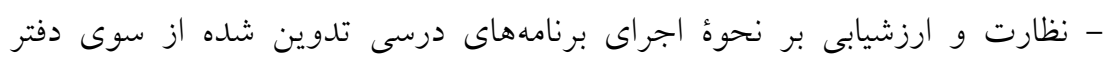

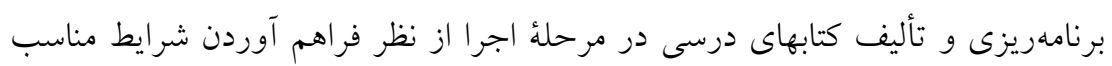

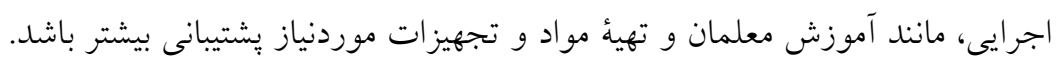

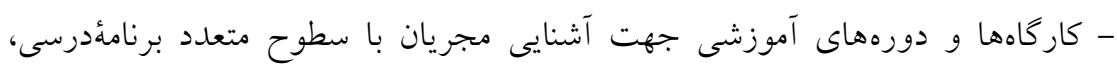

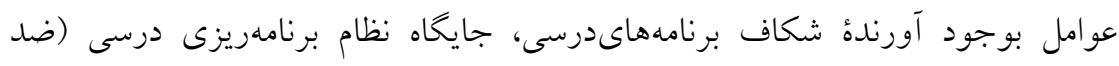

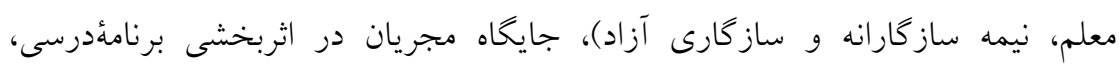

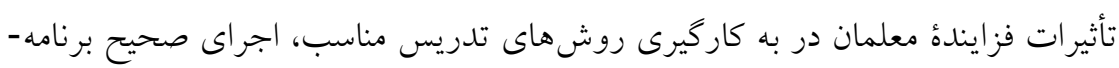

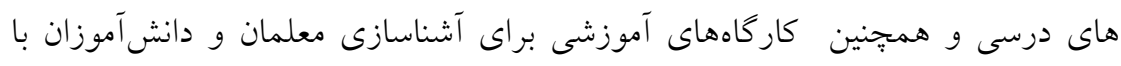
نقش سبكهاى يادگيرى و راهبردهاى مطالعه به منظور كاهش شكاف و هماهنكى بيشتر برنامههاى درسى ياد شده بركزار شود. 


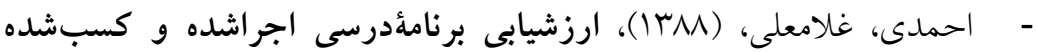
علوم دوره راهنمايى، طرح يُوهشى، وزارت آموزش و يِّورش سازمان يزّوهش و برنامهريزى آموزشى.

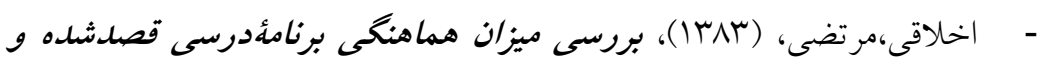

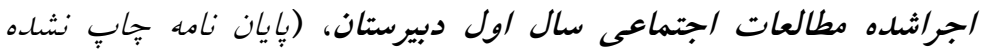

$$
\text { كارشناسى /رشد)،دانشخاه شهيد بهشتى، تهران. }
$$

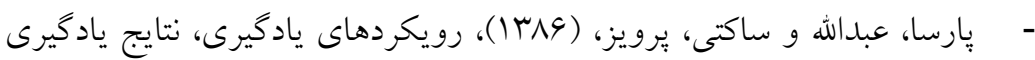

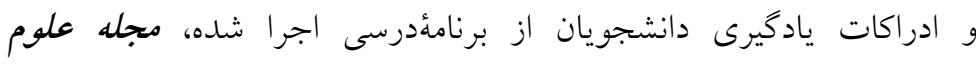

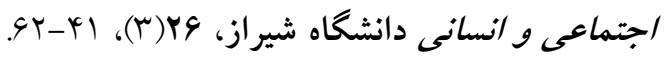

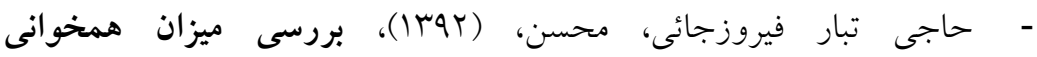
برنامهدرسى قصدشده، اجراشده و كسبشده مطالعات اجتماعى سال اول دبيرستان در شهر تهران و ارائه الكوى مطلوب، (رساله جابٍ نشده دكترى)، دانشخاه علامه طباطبايى، تهران.

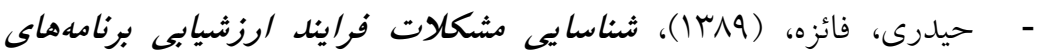
درسى از نظر كارشناسان و مديران برنامهريزى و تأليف كتب درسى، (

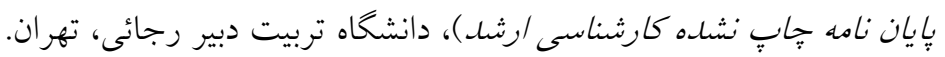

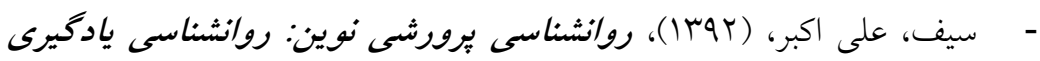
و آموزث، تهر ان: دوران.

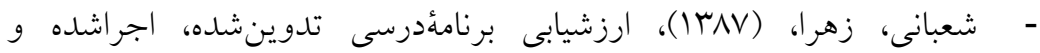

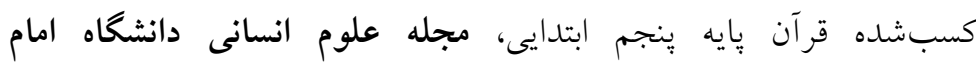

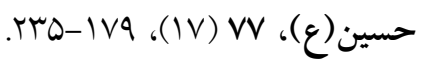




$$
\begin{aligned}
& \text { طر احى و اعتبارسنجى الخوى مفهومى كاهش فاصلة برنامهٔدرسى... } \\
& \text { - فتحىواجارگاه، كورش، (IMN1)، اصول برنامهريزى درسى، تهران: ايران } \\
& \text { زمين. }
\end{aligned}
$$

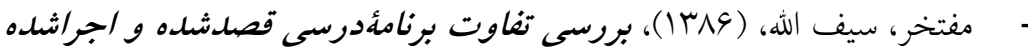

$$
\begin{aligned}
& \text { شهروند مسئول در دوره متوسطه /ز ديدگاه دبيران علوم اجتماعى، (يايان } \\
& \text { نامه جابٍ نشاه كارشناسى /رشله)، دانشخاه علامه طباطبايى، تهر ان. } \\
& \text { - موسى بور، نعمتالله و صابرى، سيد حسين، (1/19)، ارزش يابى استلزامات } \\
& \text { و اقتضائات اجرايى برنامةٔدرسى ملى جمهورى اسلامى ايران، فصلنامه }
\end{aligned}
$$

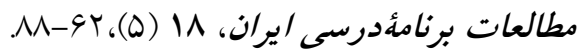

$$
\begin{aligned}
& \text { - مومنى مهمونى، حسين، كرمى، مرتضى و مشهلدى، على، (1/99)، بررسى } \\
& \text { نقش عوامل كاهشدهنده فاصله بين برنامئدرسى قصدشده، اجراشده و } \\
& \text { تجربهشده در آموزش عالى، دو فصلنامه مطالعات برنامعدرسى آموزث }
\end{aligned}
$$

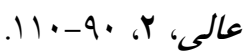

$$
\begin{aligned}
& \text { - مهرمحمدى، محمود و و همكاران، (1/99)، برنامهدرسى: نظرگاهها، } \\
& \text { رويكردها، جشم/اندازها، مشهـ: آستان قدسرضوى. }
\end{aligned}
$$

- Bekalo, Samuel and Welford, Geoff.(2001) 'Practical activity in Ethiopian secondary physical sciences: implications for policy and practice of the match between the intended and implemented curriculum', Research Papers in Education, 15: 2, 185- 212

- Connelly, F. M. \& Clandinin, D. J. (1988).Teachers as curriculum planners: Narratives of experience. New York:

Teachers College Press.

- Clarisse, A. M. H. (2011). Intended VS.Implemented. VS. Achieved- curriculum. http//www.Scribd.com/dog/ 38747022/ Intended-VS.

- Freeman, E. (2004). The stakeholder approach revisited, ZWU, 5 (3), 228-241.

- Glatthorn, A.A, Boschee, F, White head, B.m, Boschee,B.F. (2012). Curriculum leader ship: Strategies for Development 
and Implementation third Ed, Thousand Oaks,California, SAGE, Inc.

- Glatthorn, A.A, Jailall, J. M. (2009) The Principal as Curriculum Leader: Shaping What Is Taught and Tested.third Ed, Thousandoaks, SAGE, Inc.

- Menis, Joseph.(1994). Chemistry in Israeli 12 th Grade Classes: the intended, implemented and the achieved curricula. \{Electronic version \} Studies in Educational evaluation, 20, 349-363.

- A study of textbooks as the potentially implemented curriculum Monica,J(2003. Department of Mathematics Lulea university of technology. SE-971 87 Lulea, SWEDEN.

- Norris, K. (1998). Professional Growth: New approaches Indicating change In the culture of shools http:

//www.klingestein.org/Additional-Resources/Projects/1998.

- Polit, D. \& Beck, C. \& Owen, S. (2007). Is The CVI and Acceptable Indicator of content Validity? Appraisland Recommendations. Research in Nursing \& Heath, 30, 459467.

- Pons, P \& Beck, C. (2006). The content Validity Index: Are you Know Whats Being Reported? Critique and Recommendations.Research in Nursing \& Heath, 29.489-97.

- Robitaille. D.F.et al(1993). Curriculum Framework For Mathematics and science Canada IEA.

- Schmidt,M.H.et al (1997). Many visions, many aims: across national investigation of curricular intentions in school Mathematics (vol.1). Dordrecht : Kluwer.

- Terence, S. P. (2011). Assessing the curriculum .Dangkusay. http//www.Scribd.com/dog/ 61986229/ Intended-VSImplemented- VS- Achieved- curriculum

- Tshering, Y (1998).The Intended and the Taught curriculum in Grade 6 Geography in Bhutan :A curriculum Audit. In the Department of curriculum and Instruction, The university of new RUNSWICK.April. 